\title{
A review of the diversity and impact of invasive non-native species in tropical marine ecosystems
}

\author{
Parisa Alidoost Salimi ${ }^{*}$, Joel C. Creed ${ }^{2}$, Melanie M. Esch ${ }^{3}$ DD, Douglas Fenner ${ }^{4}, Z_{\text {Zeehan Jaafar }}^{5}$, Juan C. Levesque ${ }^{6}$, \\ Anthony D. Montgomery ${ }^{7}$, Mahsa Alidoost Salimi ${ }^{1}$, J. K. Patterson Edward ${ }^{8}$, K. Diraviya Raj ${ }^{8}$ and Michael Sweet ${ }^{9}$
}

\begin{abstract}
Tropical marine ecosystems are biologically diverse and economically invaluable. However, they are severely threatened from impacts associated with climate change coupled with localized and regional stressors, such as pollution and overfishing. Non-native species (sometimes referred to as 'alien' species) are another major threat facing these ecosystems, although rarely discussed and overshadowed by the other stressors mentioned above. NNS can be introduced accidentally (for example via shipping activities) and/or sometimes intentionally (for aquaculture or by hobbyists). Understanding the extent of the impacts NNS have on native flora and fauna often remains challenging, along with ascertaining when the species in question actually became 'invasive'. Here we review the status of this threat across key tropical marine ecosystems such as coral reefs, algae meadows, mangroves, and seagrass beds. We aim to provide a baseline of where invasive NNS can be found, when they are thought to have been introduced and what impact they are thought to be having on the native ecosystems they now inhabit. In the appended material we provide a comprehensive list of NNS covering key groups such as macroalgae, sponges, seagrasses and mangroves, anthozoans, bryozoans, ascidians, fishes, and crustaceans.
\end{abstract}

Keywords: Coral reefs, Seagrass, Mangroves, Invasive, Non-native species, Disease, Tropical marine ecosystems

\section{Background}

Tropical marine ecosystems (TMEs) are biodiverse and include a variety of habitats, such as coral reefs, mangrove forests, seagrass beds, and algae meadows (Hansen 2003). Collectively TMEs support billions of people worldwide (Kaufman and Dayton 1997, Moberg and Folke 1999, Barbier et al. 2011), providing ecosystem services, such as coastal defence, fisheries, recreation and tourism, and carbon sequestration (Barbier 2017). Furthermore, coastal TMEs represent an important interface between land and sea, controlling nutrient fluxes and material exchange from terrestrial to open ocean environments (Barbier 2017). However, these

\footnotetext{
*Correspondence: P_Alidoostsalimi@yahoo.com; P.Alidoustsalimi@srbiau.ac.ir ${ }^{1}$ Department of Marine Biology, Science and Research Branch, Azad University, Tehran, Iran

Full list of author information is available at the end of the article
}

habitats are facing unprecedented stressors in the Anthropocene (the epoch associated with humankind) including human mediated climate change as well as local and regional stressors such as over exploitation, coastal development, pollution, and the introduction of non-native species (NNS) (Hansen 2003, De Poorter et al. 2009). NNS, which are often referred to alternatively as 'alien', 'non-indigenous', 'introduced' or 'exotic', include any species occurring outside its natural past or present range, dispersed by direct or indirect, intentional, or unintentional human activities (Walther et al. 2009). The term invasive non-native species (or invasive alien) is used when the species becomes established in its new home, spreads outside the introduction area and poses a threat to the native wildlife, the ecosystem functioning, economics, human health and/or

(c) The Author(s). 2021 Open Access This article is licensed under a Creative Commons Attribution 4.0 International License, which permits use, sharing, adaptation, distribution and reproduction in any medium or format, as long as you give appropriate credit to the original author(s) and the source, provide a link to the Creative Commons licence, and indicate if changes were made. The images or other third party material in this article are included in the article's Creative Commons licence, unless indicated otherwise in a credit line to the material. If material is not included in the article's Creative Commons licence and your intended use is not permitted by statutory regulation or exceeds the permitted use, you will need to obtain permission directly from the copyright holder. To view a copy of this licence, visit http://creativecommons.org/licenses/by/4.0/. 
society in general (Walther et al. 2009, Teixeira and Creed 2020).

NNS can be introduced and subsequently spread in tropical waters via several different pathways, like any other aquatic environments. However, the relative importance of invasion vectors remains difficult to assess as linking a specific vector with a certain invasion is often impossible. In general, international shipping activities, including ballast water exchanges and vessel fouling, are usually blamed, and are identified as the two primary routes for many species reaching new habitats (Ruiz et al. 1997, Godwin 2003, Molnar et al. 2008). Aquaculture is likely the next major source of NNS within a region as in some cases escapes of the cultured species may occur from farms. Further, nontarget species may inadvertently be introduced as hitch hikers with the imported stock (De Silva et al. 2009, Cagauan 2007). Other pathways include introductions from aquaria and zoos or the hobbyist trade, via recreational activities, tourist activities, and transport on marine litter or debris (Bax et al. 2003, Padilla and Williams 2004, Anderson et al. 2015).

When a NNS is introduced to a new region, there are several obstacles the species need to overcome before it becomes a successful invader. In the tropics, for example, where there is typically high natural biodiversity, complex biotic interactions of the native communities often make it difficult for NNS to get a foothold (Kennedy et al. 2002, Kühn and Klotz 2008, Wells and Bieler 2020). Although, this is not always the case and some tropical areas have lower than average diversity, Hawaii and the eastern Pacific for example. Regardless, if introduced species do manage to attain high abundances, they have the potential to displace native species, affect ecosystem processes, change community structure, impact human health, decrease native biodiversity and cause substantial economic losses (Mack et al. 2000, Grosholz 2002, Bax et al. 2003, Simberloff 2005). Although not all NNS will have such direct negative impacts in their recipient systems (Simberloff 2005, Goodenough 2010), the subsequent introduction of nonnative parasites and possibly pathogenic microorganisms which may occur with any host might be more of a threat (Young et al. 2017). Indeed, this latter aspect of NNS is so poorly understood in the tropics, there are only a few marine examples that can be drawn upon to highlight this impact (see section 5).

Here, we aim to creat a baseline data set and review of where NNS can be found with marine ecosystems of tropical regions (including Topical Atlantic, Indo-Pacific and Eastern Tropical Pacific; Spalding et al. 2007) (Fig. 1). We focused our review on invasive NNS, as by definition these species have much greater impacts on the marine ecosystem they inhabit and are much less numerous than other NNS. Further, due to the large number of documented NNS in general our goal was not to present a complete list of species present, but instead, highlight key tropical marine taxa, such as algae, marine plants (mangroves and seagrass), sessile invertebrates (sponges, bryzoans, ascidians and corals) and fish

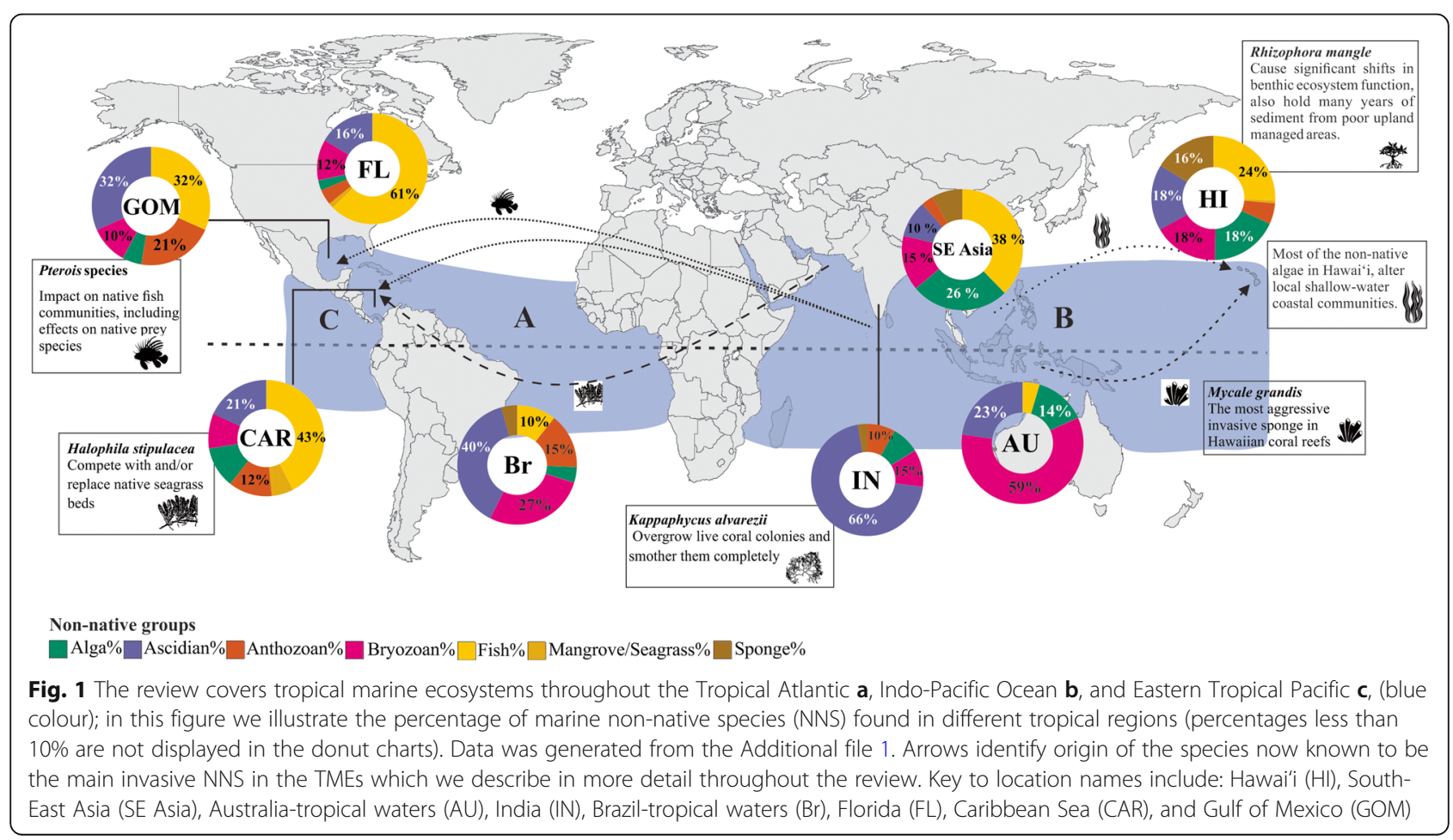


- and specific examples within these groups. We also attempt to summarize invaded tropical regions, assess introduction pathways for each NNS, explore the threat to native biodiversity and the TMEs where possible (see Additional files 1 and 2).

\section{Algae}

Marine macroalgae are a major component of NNS globally, with current estimations of introductions in excess of 300 species (Davidson et al. 2015). Many non native (NN) algae, start off in aquaculture or in harbors transported via the ballast water of ships, currents will then often transport the NNS throughout their new habitats (Hewitt et al. 2007, Williams and Smith 2007, Dubinsky and Stambler 2010). However, this is an over generalization as the pathways of $40 \%$ of $\mathrm{NN}$ algae globally remains unknown (Williams and Smith 2007). Here we have identified 57 marine $\mathrm{NN}$ algae in tropical regions (Additional file 1). Hawai' $\mathrm{i}$ stands out as having the highest number of $\mathrm{NN}$ algae (Additional file 2), some of which directly or indirectly threaten local coral reef ecosystems and seagrass beds. Take the red alga Kappaphycus alvarezii, for example. This invasive NNS was extensively farmed in the Philippines in the 1960s (Bixler 1996, Sulu et al. 2004), in Hawai'i from 1970 (Conklin and Smith 2005) and in the Gulf of Mannar from 1990 (Kamalakannan et al. 2014). Established populations have since spread outside the farmed area, and it is recognised as an established NNS in India, Tanzania, Panama, Venezuela, Hawai'i and Fiji (Rodgers and Cox 1999, Ask et al. 2003, Chandrasekaran et al. 2008, Sellers et al. 2015a). This destructive tropical red alga is mostly cultured very close to coral ecosystems and its negative impacts have been recorded on coral reefs in many areas, such as Kāne'ohe Bay in Hawai'i and the Gulf of Mannar, India (Rodgers and Cox 1999, Chandrasekaran et al. 2008, Patterson Edward and Bhatt 2012). K. alvare$z i i$ triggers decline in the density and diversity of native fish and brings down the species richness and abundance of native macroalagae, coral and other benthic macrofauna (MoEF\&CC Project Report 2018, Neilson et al. 2018, HISC 2019).

Evidently, the success of $K$. alvarezii is related to its fast growth rate. In Hawai'i, the rate of spread is estimated to be $250 \mathrm{~cm}$.year ${ }^{-1}$ with an average growth rate of 5.06\% day ${ }^{-1}$ (Glenn and Doty 1990, HISC 2019). In just over 2 years the alga increased its cover from less than $10 \%$ to more than $50 \%$ (Conklin and Smith 2005). In the Gulf of Mannar K. alvarezii grows over live coral colonies and smothers them completely (Chandrasekaran et al. 2008, Patterson Edward and Bhatt 2012, Edward et al. 2015, MoEF\&CC Project Report 2018). This overgrowth can cause a coral-algal phase shift in short periods of time (Conklin and Smith 2005, MoEF\&CC
Project Report 2018), especially when compounded by overfishing of the herbivorous fish species which graze the NN algae (Dubinsky and Stambler 2010). However, even when herbivory was reported as high, $K$. alvarezii appears to be less preferred by many species and so is less grazed (Smith et al. 2002, Conklin and Smith 2005).

Interestingly, coral bleaching might, inadvertently, be the answer to controlling $K$. alvarezii, which appears to not be able to survive on dead coral skeleton (MoEF\&CC Project Report 2018, Barnhill and Bahr 2019). Although we recognize that this is not a 'management strategy', it does offer a window into the future of these ecosystems and phase shifts from coral reef to alga $K$. alvarezii are unlikely to occur with the demise of coral reefs. While phase shifts have been reported in other regions when corals decline in abundance and the ecosystem's herbivores are not present to control algae overgrowth - for example throughout much of the Caribbean (Mumby 2009). In this case, when the corals recover (possibly through extensive restoration practices), there is of course nothing to prevent the remnants of $K$. alvarezii from repopulating and invading the recovering reefs- this will obviously hamper efforts to protect this fragile ecosystem (MoEF\&CC Project Report 2018, HISC 2019).

Other non-native red algae such as Gracilaria salicornia, Acanthophora spicifera and Hypnea musciformis are also known to cause many problems in Hawai i. G. salicornia was first introduced in the 1970s for experimental aquaculture for the agar industry (Smith et al. 2002, 2004). It quickly monopolizes any available substrate and, in many areas, has become the single-most dominant benthic species in the region. Before the invasion, much higher diversities of algae species were commonly encountered (over 60 species in some examples) (Smith et al. 2004). This invasive NNS is also able to significantly acidify the water which leads to the decline of coral reefs (Martinez et al. 2012). A. spicifera was first detected in Hawai'i in the 1950s and has since been recorded at Palmyra Atoll in 2002 and 2008 (Russell 1992, Russell and Balazs 1994, Knapp et al. 2011), whilst $H$. musciformis was first introduced in 1974 for commercial cultivation. These invasive species are frequently observed smothering reef organisms such as corals and native algae (Smith et al. 2002). The rapid dispersal of all three NNS is associated with fast growth rates, morphological plasticity, abundant production of tetraspores (reproduction strategy) and their ability to be epiphytic on other algae (Russell 1992, Smith et al. 2002). Interestingly, there may be a glimmer of hope in the form of the green turtle (Chelonia mydas). These turtles appear to prefer consumption of NN algae (when given a choice), and so may act as a natural control mechanism preventing the complete overtake of the TMEs by these NNS (Russell and Balazs 1994, Russell and Balazs 2015). 
Two other species of invasive NN algae, worthy of note are the green algae Avrainvillea erecta and A. amadelpha, which were 'accidentally' introduced to Hawai i in the early 1980s. These algae have since become established in sandy and hardbottom habitats which were originally dominated by the endemic Hawaiian sea grass (Halophila hawaiiana), (Martinez et al. 2009, Peyton 2009, Wade et al. 2018). However, although these NN algal meadows contain approx. 95\% more biomass than the seagrass meadows, $H$. hawaiiana appears the superior competitor, which led researchers to suggest the seagrass would naturally suppress the algae mats preventing complete colonization (Peyton 2009).

Impacts associated with invasive $\mathrm{NN}$ algae are generally perceived to be negative, however as the above examples indicate, this can vary and in fact, less than $12 \%$ of $\mathrm{NN}$ algae are thought to be a major threat to TMEs (Additional files 1 and 2). However, this value may likely change once further research monitors the continued spread and succession of these NNS in these habitats.

\section{Marine plants Mangroves}

Native mangrove plants are essential habitat for many marine species in tropical and subtropical regions but predicting and understanding how mangroves become established as NNS and subsequently flourish is challenging. That said, there are several well-documented introductions of mangroves in non-native habitats, which offers us clues about how these species become established over time. For example, humans have intentionally introduced non-native mangroves to both non-native (e.g., Moloka'i, Hawaiii) and native (e.g., Bangladesh, China, South Florida, and Tonga) mangrove regions around the world (Fourqurean et al. 2010). In 1902, the red mangrove (Rhizophora mangle), originally from South Florida was introduced to Moloka'i, Hawai'i with the intent to stabilize the shoreline (Chimner et al. 2006). Fifteen years later it was introduced to O'ahu for the same purpose (Allen 1998). The red mangrove and the buttonwood (Conocarpus erectus), which both originate from South Florida, along with the upriver orange mangrove (Bruguiera sexangular), the lenggadai (Bruguiera parvifolia), the spurred mangrove (Ceriops tagal) and the Asiatic mangrove (Rhizophora mucronate), all from the Philippines were later introduced in $\mathrm{O}^{\prime}$ ahu in 1922 (Allen 1998). However, only the red mangrove and the upriver orange mangrove became well established. The red mangrove in particular has successfully invaded all the main Hawaiian Islands except Kaho'olawe and $\mathrm{Ni}^{i}$ ihau (Allen 1998). Mangroves are now found on every coast in O'ahu except the dry leeward coast (Allen 1998). Removal projects are underway yet NNS stands still exist, although some populations have been reduced in recent years.

In Miami, Florida, two Indonesian Tumu mangrove trees (Bruguiera gymnorrhiza) were planted in the intertidal zone in 1940, and the white-flowered black mangrove (Lumnitzera racemose) was introduced multiple times during the mid-1960s and early-1970s (Fourqurean et al. 2010). Today, the Tumu and white-flowered mangrove populations are expanding throughout South Florida at around 5.6 and $17-23 \%$ per year, respectively (Fourqurean et al. 2010). They can compete with native species because their natural environments (Indo-Pacific), life-history characteristics, and genetics are similar to native mangroves, including the frequency of disturbance at the introduction sites (Fourqurean et al. 2010).

Non-native mangroves in general can alter chemical and physical conditions and cause numerous problems in regions where they do not naturally occur like Hawai' $i$ for example. The red mangrove causes obnoxious odors (anoxic conditions) and clogs tidal streams (Chimner et al. 2006). Non-native mangroves can also cause significant shifts in benthic ecosystem function, with sediment metabolism, benthic community structure and short-term C-remineralization dynamics being affected for up to 6-years following invader removal (Sweetman et al. 2010). Non-native mangroves can also restrict tidal flow, and lower dissolved oxygen concentrations (Allen 1998); low flow and anoxic conditions can also cause toxic algal blooms (Chimner et al. 2006). Moreover, mangrove roots can trap fine and organic-rich sediment, which alters benthic communities and has long-term and broad implications for native marine fauna (Demopoulos and Smith 2010). Also, the red mangrove can negatively impact native biodiversity, especially in coastal fish ponds and habitat quality for endangered shorebirds, such as the Hawaiian stilt (Himantopus mexicanus knudseni) and the Hawaiian moorhen (Gallinula chloropus sanvicensis) (Allen 1998, Chimner et al. 2006). Nonnative mangroves are not only fast growing, but they can crowd out native species. In Hawai' $i$, all mangroves are non-native and have colonized many different coastal habitats, including tidal flats, riverbanks, fishponds, canals, protected reefs, embayments, lagoons, and other protected areas (Chimner et al. 2006). It should be noted that there is debate on the removal of them in some areas. While they may impact native biodiversity and alter native shorelines, they are also holding many years of sediment from poorly managed upland areas, so removing them may increase sediment onto the reefs offshore. Previous removal efforts have focused in specific areas where managers have the ability to control the population. However, there is no data to demonstrate the positive or negative impacts of their removal in these areas. 
Mangrove ecosystems themselves often resist invasion of other NNS, because the harsh saline conditions do not allow most other invasive plants and trees to establish (Lugo 1998). However, non-native mangroves in Hawai'i have facilitated the establishment of other NNS, such as the Samoan crab (Scylla serrata), barnacles (e.g., Chthamalus proteus, Amphibalanus reticulatus, and Amphibalanus amphitrite) and sponges (e.g., Suberites aurantiacus, Haliclona (soestella) caerulea, and Gelloides fibrosa) (Eldredge and Smith 2001, Demopoulos and Smith 2010). Impacts associated with the introduction of non-native mangrove plants are generally perceived to be negative, but some studies suggest positive impacts through the increase in the abundance and diversity of species occurring in an area (Demopoulos et al. 2007).

\section{Seagrass}

Seagrasses can rapidly grow in new areas through vegetative propagation, altering the seascape, and transforming soft sandy bottoms into areas of submerged aquatic vegetation (Steiner and Willette 2015, Smulders et al. 2017). Initially monospecific patches will form but with high growth rates, meadows soon proliferate if given a chance (Willette and Ambrose 2009). Halophila stipulacea's native range is from India to the eastern continent of Africa, Madagascar, the Red Sea and the Persian Gulf (Den Hartog 1970, Short et al. 2007). This species is often referred to as a 'lessepsian migrant' (i.e. invaded the Mediterranean Sea through the Suez Canal, which opened in 1869) (Gambi et al. 2009). From the canal it spread west to Malta, the Ionian Sea and northern Sicily (Willette and Ambrose 2009). In 2002 for the first time the occurrence of this NNS was documented in the tropical waters off the Caribbean coast of Grenada, West Indies (Willette and Ambrose 2009, Willette et al. 2014, Ruiz et al. 2017), and subsequently in the British Virgin Islands and Puerto Rico (Ruiz et al. 2017) and west to Aruba and the Venezuelan mainland (Vera et al. 2014, Willette et al. 2014). This species has extended its range dramatically, roughly $700 \mathrm{~km}$ over 15 years (Chiquillo et al. 2019). Spread is likely facilitated by boats (on anchors or intertwined with fishing traps) and/or more 'naturally' via ocean currents (Ruiz and Ballantine 2004, Willette and Ambrose 2012, Willette et al. 2014, Ruiz et al. 2017). Until recently it was thought that Caribbean populations disseminated exclusively by fragments of natural and anthropogenic origin, yet flowers and fruits have since been recorded in Caribbean populations throwing doubt onto this hypothesis (Vera et al. 2014, Chiquillo et al. 2019, Willette et al. 2020).

H. stipulacea competes with native seagrass often replacing species such as Syringodium filiforme, Halodule wrightii, $H$. decipiens and even the climax species Thalassia testudinum (Willette and Ambrose
2012, Steiner and Willette 2015, Smulders et al. 2017, Christianen et al. 2019). Although $H$. stipulacea sometimes presents a sparse growth form, which does not overgrow the local seagrasses, it can often form an understory layer preventing other species propagating themselves (Van Tussenbroek et al. 2016). $H$. stipulacea is also highly resilient to small-scale disturbance and may grow into damaged areas 1.5-30 times faster than native seagrasses (Willette et al. 2020). It is therefore likely to thrive under situations of anthropogenic impact such as poorly flushed Caribbean bays, which are often subjected to high nutrient inputs and physical damage in harbours and anchorages (Olinger et al. 2017). Moreover, grazers such as green turtle (Chelonia mydas) may modify the rate and spatial extent of this invasive species' expansion, due to grazing preferences, and increased space for settlement (Becking et al. 2014, Christianen et al. 2019).

Canopy heights of $H$. stipulacea are much lower than native seagrasses (Olinger et al. 2017) so it also alters the abundance and composition of seagrass-associated organisms, with knock-on effects at different trophic levels (Willette and Ambrose 2009, Boman et al. 2019). For example, $H$. stipulacea patches have been documented to harbour reduced fish diversity and alter juvenile fish assemblages, with an abundance of some nocturnal carnivores and scarcity of herbivores and diurnal carnivores (Olinger et al. 2017).

$H$. stipulacea is an exceptional ecologically flexible invasive NNS and although it can provide new seagrass habitat (Willette and Ambrose 2012, Pinault et al. 2018), its continued expansion (Rogers et al. 2014) may: 1) compromise seagrass ecosystem functioning (Smulders et al. 2017); and 2) negatively interact with $H$. engelmanni and $H$. baillonii, both of which have small ranges and are listed as "vulnerable" by the IUCN (Short et al. 2011, Willette et al. 2014).

Native seagrass communities are also almost certainly affected by several other invasive NNS (Hansen 2003), yet there is little literature on any specific impacts. In this regard, Williams (2007) listed 56 known NNS in seagrass beds. Of those only four macroalgae (K. alvarezii, Eucheuma denticulatum, A. amadelpha and Caulerpa ollivieri have been introduced into tropical seagrass meadows. Furthermore, the IndoPacific lionfish Pterois volitans (Claydon et al. 2012) and Indo-Pacific green mussel Perna viridis (Buddo et al. 2003) have been reported in tropical Caribbean seagrass beds. The invasive swimming crab Charybdis hellerii, native to the Indo-West Pacific, occurs almost exclusively in dense $H$. stipulacea beds rather than sparse ones, native seagrass beds, sand, rocks or algae (Ferry et al. 2017). 


\section{Sessile invertebrates Sponges}

In the context of NNS, sponges have received little attention in TMEs, and their impacts remain largely unknown. However, it does appear that invasive NN sponges are able to compete for space with native sponges and corals, thereby posing a possible threat to reef ecosystems as their health declines due to climate change (Eldredge and Smith 2001). The transfer of NN sponges is likely accidental, through shipping, commercial trawling, and marine aquaculture (Godwin 2003, Carballo et al. 2013, Klautau et al. 2020). According to our database, 34 marine $\mathrm{NN}$ sponges have been documented in tropical regions (with the highest numbers again reported from Hawai'i), (Additional files 1 and 2). For example, the orange keyhole sponge (Mycale grandis), native to Indonesia, was unintentionally introduced to Hawai' $\mathrm{i}$ in 1996 (Coles et al. 2007, Coles and Bolick 2007). Unlike the majority of other $\mathrm{NN}$ sponges found in Hawai' $i$, this aggressive alien sponge has been described as a major threat to corals as the observed long-term sustained biomass implies adaptability of this species to future climate change scenarios/environments (Coles et al. 2007, Coles and Bolick 2007, Shih 2018). This invasive NNS is able to withstand high $\mathrm{pCO}_{2}$ and high temperatures which have proven stressful for many other reef organisms (Vicente et al. 2016). Biomass of $M$. grandis increased throughout the mid-2000s and the sponge remains a prominent member of the benthic community in Kāne ohe Bay and other partially degraded shallow coral reef ecosystems in Hawai' $i$ (Shih 2018). Large clusters of this species are often present in shaded areas such as along pier pilings and docks, but it also grows in clear and shallow locations on the reef.

In the Mexican Pacific, another NN sponge, Chalinula nematifera (originally native of the Indo-Pacific) was first identified in 2003 on coral reefs in the Isla Isabel National Park. C. nematifera overgrows corals, as well as dead skeletons and coralline algae (Ávila and Carballo 2009, Turicchia et al. 2018). This specise grows at a rapid rate $\left(50 \mathrm{~mm} \cdot \mathrm{mo}^{-1}\right)$, which is comparatively higher than most of the native sponges in the Mexican Pacific. With such a rapid rate of spread, there is the high potential for this sponge to dominate coral reefs in these regions (Rossi et al. 2015, Turicchia et al. 2018).

The other NN sponges we were able to find evidence of (Additional file 1) are even less well understood than the above examples. One explanation for this may be the lack of studies which even explore these species in their traditional home ranges, those throughout the IndoPacific in this instance (Van Soest et al. 2012, Carlton and Eldredge 2015). Further, we can also not rule out that some of these 'NNS' may not be non-native, as the invasion pathways and origin of many of them are not clear to date (see Additional files 1 and 2).

\section{Bryozoans and ascidians}

Fouling organisms such as bryozoans and ascidians (tunicates) frequently constitute the majority of NNS recorded, as they attach regulary to any natural and man-made structures (McCann et al. 2007, Shenkar and Swalla 2011). Shipping is again thought to be one of the major pathways for their introductions (Lambert and Lambert 1998, Lambert 2002, see Additional file 2). These organisms are also known to spread through aquaculture (i.e., transport of contaminated shells or shellfish between mariculture operation), rafting of floating debris carried by ocean currents, and attached to live species (Lambert 2001, Bernier et al. 2009, Tamilselvi et al. 2011). For example, 49 species of Western Pacific coastal bryozoans were found on 317 floating objects that originated from the Great East Japan Earthquake and Tsunami of 2011 (McCuller and Carlton 2018). These objects (and their hitchhikers) drifted across the North Pacific Ocean and landed in Hawai'i and North America (McCuller and Carlton 2018). As the majority of the drifting objects were plastics, one can therefore classify the species carried upon them as true NNS (Stelfox et al. 2020).

These fouling organisms dominate ports and harbors (Marins et al. 2010, Sheets et al. 2016), and their impacts therefore have a direct economical aspect (Eldredge and Smith 2001, Lambert 2002, Miranda et al. 2018c). They have also been shown to decrease species richness in general, act as habitat modifiers, impact on many epifaunal species and change biodiversity by overgrowing and competing with native species (Wallentinus and Nyberg 2007, Lutz-Collins et al. 2009, Shenkar and Swalla 2011). NN tunicates for example compete with several commercially important aquaculture species, such as mussels. This is done via competition for food (plankton in the water column) and/or occupation of the settlement space (Tamilselvi et al. 2011, Zhang et al. 2019). However, healthy natural ecosystems such as coral reefs (often characterised by high biodiversity) appear able to resist the establishment of $\mathrm{NN}$ ascidians (Kennedy et al. 2002, Lambert 2002). In Guam, for example, most NN ascidians are confined to harbor structures and have not yet significantly colonized natural reef tracts (Lambert 2002).

We found $125 \mathrm{NN}$ bryozoans and ascidians documented in shallow waters and coastal areas (Additional file 1). However, owing to the lack of systematic and biogeographical data on native species and natural diversity of these groups the number of NNS is likely to be an underestimate. Some species have wide geographical 
distributions, and it is impossible to rule out historical introductions before baseline studies assessed their home ranges. Take Amathia verticillata for example (one of the most widely recorded NNS in the world; Marchini et al. 2015, Minchin et al. 2016, McCann et al. 2015, Collins et al. 2020). Such a cosmopolitan distribution has posed questions as to its real native origin and many are arguing that despite first being described in Italy, its origin may have been the Caribbean (Galil and Gevili 2014, Marchini et al. 2015, Miranda et al. 2018c). A. verticillata's economic impact comes from its extensive fouling behaviour on harbors and marinas, as well as on the vessels and fishing gear, and it has been known to clog water intake pipes (Miranda et al. 2018c). Also, this NNS is known to cause local biodiversity impacts due to its dominance over native species (Miranda et al. 2018c). Furthermore, several studies have highlighted that other fauna (such as bryozoans, nudibranchs, amphipods and isopods) are associated with this bryozoan. A. verticillata itself is therefore likely a special niche for smaller NNS, enhancing opportunities for their spread as well (Farrapeira 2011, Marchini et al. 2015).

Although NN bryozoans and ascidians are common and diverse, they do appear largely restricted to harbors and ports, struggling to gain a foothold in natural ecosystems (Lambert 2001, Ali et al. 2009). For this reason, they do have an economic impact which warrants attention, however their ecological impact in TMEs may be much less than other groups of NNS. However, there is no guarantee that this will remain as such as these systems change and transgress in a changing world.

\section{Hard and soft corals}

Although not the first thought when discussing NNS, there are several classic coral examples which we can draw on here (see Additional file 1), such as the three scleractinians Tubastrea coccinea, T. tagusensis, and T. micranthus. Of these, T. coccinea and T. tagusensis are considered highly invasive NNS and cause significant environmental, economic, and social impacts as they spread in Brazil (Creed 2006, Lages et al. 2011, Mantelatto and Creed 2015). T. micranthus has a similar potential for negative impacts although less studied to date (Sammarco et al. 2010, 2013, 2014). Interestingly, T. coccinea and T. tagusensis co-occur in many areas, growing on top of each other and often coalescing (Creed et al. 2017b). They often exclude native corals (Creed 2006, dos Santos et al. 2013, Miranda et al. 2016b) and other invertebrates (Silva et al. 2019) where they grow, modifying coral recruitment and fish assemblages (Miranda et al. 2018a, b), transforming communities and seascapes (Lages et al. 2011, De Paula et al. 2017, Capel et al. 2020), and impacting ecosystem service provision (Mantelatto and Creed 2015, De Paula et al. 2017). They are proven effective invaders as they exploit multiple reproductive modes and are fast growing (Mizrahi et al. 2014, De Paula et al. 2014, Capel et al. 2017, Luz et al. 2018). They also employ physical and chemical defenses against competitors and predators (Lages et al. 2010a b, Lages et al. 2012, dos Santos et al. 2013).

Originally from the Indo-Pacific, these species are widely found throughout the tropical and sub-tropical Atlantic including Brazil, throughout the Caribbean Sea, the Gulf of Mexico (GOM), and the Canary Islands (Creed et al. 2017a, López et al. 2019). T. coccinea and T. micranthus naturally occur in the Indo-Pacific (Cairns and Zibrowius 1997, Sammarco et al. 2013), whilst T. tagusensis was originally restricted to the Galapagos Archipelago (Ecuador) (Wells 1982, Glynn and Wellington 1983).

T. coccinea was first reported as a NNS in 1943 in Aruba and Puerto Rico (Western Atlantic) (Vaughan and Wells 1943, Fenner and Banks 2004). Currently, its non-native range extends to the Caribbean Sea, the GOM (Fenner 2001), Florida (Fenner and Banks 2004) and Georgia (Creed et al. 2017a), the southwestern Atlantic (late 1980s) (Fenner 1999, De Paula and Creed 2004, Miranda et al. 2016a, de Faria and Kitahara 2020), and recently the Canary Islands (López et al. 2019).

T. tagusensis similarly has been reported as cryptogenic in the Persian Gulf (Creed et al. 2017a), nonnative in the Brazilian southwest Atlantic (De Paula and Creed 2004, Mantelatto et al. 2011, Sampaio et al. 2012, Creed et al. 2017a, de Oliveira Soares et al. 2018), in GOM on artificial reefs and oil platforms (Figueroa et al. 2019), and in the Canary Islands (López et al. 2019). T. tagusensis has likely been in the Caribbean and GOM for $>15$ years and historically overlooked (Joel Creed pers. obs. in photographs and T. Shearer, pers. communication). Therefore, it is possible that it arrived together with T. coccinea prior to 1943 in the Atlantic and in the 1980s and 2010s in Brazil and the Canary Islands, respectively.

The third species, T. micranthus, is thus far only found on oil and gas platforms operating in the (extra-tropical) northern GOM - with reports of colonies at depths $\leq 183 \mathrm{~m}$ (Sammarco et al. 2010, 2013, 2014). Interestingly, a fourth, yet unidentified clade of Tubastraea (with intermediate characteristics) has also been recognized in the GOM (Figueroa et al. 2019) and Brazil (Joel C. Creed, pers. obs.), but additional taxonomic work needs to be completed to determine its status or significance - note the whole genus likely needs revision (Capel et al. 2019).

Creed et al. (2017a) reviewed pathways and vectors of Tubastraea spp. and concluded that their introduction to the Caribbean and GOM was from fouling on ships' hulls, especially floating platforms, and their current distribution is also a result of passive dispersal of larvae by 
currents. In the southwest Atlantic, Gabon, and the Canary Islands, Tubastraea spp. were likely introduced through biofouling on oil platforms and/or drill ships, probably redeployed from western Africa, the GOM, or other areas throughout the Indo-Pacific (Friedlander et al. 2014, López et al. 2019, Creed et al. 2017a). Except for the Caribbean, the earliest records of Tubastraea in the Atlantic are on oil platforms and genetic studies have further confirmed that oil platforms serve as the most likely vector (Capel et al. 2019).

In addition to Tubastraea other scleractinians have also become NNS. For example, the mushroom coral Lobactis scutaria (previousely known as Fungia scutaria) is native to the Indo- and Central Pacific and Red Sea, but in 1966 it was introduced to Discovery Bay, Jamaica from Eilat, Israel. Specimens were held on the reef for laboratory-based experiments at the Discovery Bay Marine Laboratory where they remained until Thomas F. Gorwau (the researcher working on them) died in 1970 (Bush et al. 2004). Over the next 10 years, several attempts to eradicate this species were made with 25 adult individuals removed (LaJeunesse et al. 2005), but two additional individuals were found in 2003 (Bush et al. 2004). The fact that the species survived so long was considered by Bush et al. (2004) "as an ominous warning of potential future invasions by other tropical marine species". The ecological impact however is thought to be minor for this NNS and its successful eradication may have now occurred with the removal of these remaining two colonies (LaJeunesse et al. 2005). This example is unusual in that it was introduced by scientists. Similarly, Siderastrea siderea was introduced into Pacific Panama as five skeleton blocks thought to be dead and used in an experiment, but then discovered to be living and named Siderastrea glynni by Budd and Guzma'n (1994). All known colonies were collected and are kept in aquaria (Glynn et al. 2016).

There are also several soft corals that have been documented as NNS in TMEs. For example, seven octocorals including three species of Clavulariidae, two species of Xeniidae, one species of Anthothelidae and one species of Nephtheidae are considered NNS in the tropics. All three clavulariids have been introduced into the southwest Atlantic (Brazil). While Carijoa riseii is a widespread invasive fouling species (see below), Clavularia cf. viridis has only been reported from one location as an aquarium release (Mantelatto et al. 2018) and has since been removed. Another clavulariid that presents an interesting example is Stragulum bicolor. This soft coral is classified as a type 3 pseudoindigenous species (sensu Carlton 2009), i.e. a species described as 'new' after introduction and remaining unknown elsewhere). Currently this species is only found in Brazil. Its highly conspicuous appearance in areas previously surveyed and its ability to colonize artificial substrates (van Ofwegen and Haddad 2011) is evidence that it has been introduced, although it remains unclear where it may have originated from. However, the presence of this species appears to have little effect on the native community dynamics (Altvater and Coutinho 2015).

The nephtheid Chromonephthea braziliensis is another example of a type 3 pseudoindigenous species (sensu Carlton 2009). Again, first described from Brazil, it was documented to have been introduced at Cabo Frio, Rio de Janeiro, in the mid-1990s (van Ofwegen 2005, Ferreira et al. 2009). Compared to the native soft corals, it is a very large and distinctive species, with high dominance in certain sites. Similar to Tubastraea, it was most likely introduced by oil platforms and drill ships that are known to anchor at the initial site of discovery (Ferreira et al. 2006). In 1 year, a single colony has been reported to increase to 40 individuals (Ferreira et al. 2009) and the species is expanding its range slowly $(12 \mathrm{~km}$ in $\approx 25$ years). It has been shown to cause tissue mortality in the native endemic gorgonian Phyllogorgia dilatata (Lages et al. 2006, Fleury et al. 2008), although the extent of the ecological impacts remain unclear.

In 2017, another type 3 pseudoindigenous species (sensu Carlton 2009) was identified, this time a xeniid from the genus Sansibia. This soft coral was first detected on the shallow subtidal tropical rocky reefs in southeast Brazil (Mantelatto et al. 2018). To date, attempts at describing the species (via morphological and genetic analyses) have not been able to place this as one known to science (Mantelatto et al. 2018) - note the genus was only described in 2000. Interestingly, Sansibia was associated positively with some macroalgae and negatively with the zoantharian Palythoa caribaeorum, which probably provided greater biotic resistance to invasion (Mantelatto et al. 2018). This NNS was discovered at the same time and same site as both C. viridis (see above) and Erythropodium caribaeorum (Anthothelidae) - (Carpinelli et al. 2020). As all three are typical ornamental species kept by hobbyists, they were likely introduced through this route. This undescribed Sansibia sp. is currently estimated at expanding at a rate of $40 \mathrm{~m} \mathrm{yr}^{-1}$-assuming a linear and constant expansion rate (Mantelatto et al. 2018).

Moving to Venezuela now, Xenia membranacea was identified as a NNS when a single colony apprears in 2007 on the coastal coral community of Valle Seco (Allais et al. 2014). Originally from Indonesia this species has now increased in abundance, dominates substrate, overgrows native corals, and has extended its range by several kilometers. As this invasive NNS appears to have severe impacts on the native fauna and overgrows on scleractinian corals such as Colpophyllia natans and Montastraea cavernosa, this is certainly a species to watch in the coming years (Allais et al. 2014). 
The snowflake coral, Carijoa riisei, is another interesting example of a NNS in this group. C. riisei was thought to have originated from the western Atlantic (Carlton and Eldredge 2009), but is now believed to be native to the Indo-Pacific (Concepcion et al. 2010). It is now known to have a wide distribution across the IndoPacific and western Atlantic; however, its original native distribution is not known, again due to taxonomic uncertainty. In Hawai'i it was first found in 1966 (Concepcion et al. 2010) and formally recognised as a NNS in this region in 1972 (Evans et al. 1974). It can currently be found on all the Main Hawaiian Islands (Carlton and Eldredge 2009, Montgomery A. pers. obs.). While Carlton and Eldredge (2009) reported C. riisei to be introduced in Hawai' $\mathrm{i}$, Concepcion et al. (2010) concluded the origin of the Hawai'i colonies remains unknown, so there is an argument that $C$. riisei should be classified as cryptogenic for the Hawaiian Archipelago. Based on genetic analysis by Concepcion et al. (2010) it may be more likely that western Atlantic populations were introduced from the Pacific than vice versa.

C. riisei is now reported as a NNS in India - in the Gulf of Mannar (Padmakumar et al. 2011, Raghunathan et al. 2013) and as a potential NNS in the Galapagos (Collins et al. 2020). However, this determination is not based on evidence of its prior absence. In Colombia, large, dense stands of $C$. riisei are recorded but appear sporadically (Sánchez and Ballesteros 2014). In the Eastern Pacific, Carijoa grows on gorgonians instead of the black corals it grows on in Hawai'i (Antipathes griggi and $A$. grandis). Another genetic study explored the origin of these octocorals and indicated that these Eastern Pacific populations had close affinities to Western Atlantic populations suggesting they arrived into the Eastern Pacific relatively recently, probably by ship through the Panama Canal (Quintanilla et al. 2017). The rise of notoriety of $C$. riisei in the Hawaiian Islands specifically was based on the species ability to overgrow native black coral colonies (Grigg 2003). Grigg (2003) reported that depths between 75 and $110 \mathrm{~m}$ were a "virtual graveyard for black corals". Subsequent quantitative analysis of this area showed approximately $60 \%$ of the colonies between 80 and $100 \mathrm{~m}$ had been colonized by this NNS (Kahng and Grigg 2005). C. riisei appears to favour the larger black coral colonies and appears to initially attach to dead branches, then smoother the living tissue (Kahng and Grigg 2005). Interestingly, results from a survey conducted in 2006 indicated that the invasion' appears to be abating (Kahng 2007), so the current threat of the NNS remains unknown.

\section{Fishes}

Invasions by fishes, especially those occupying higher trophic levels, are much rarer in comparison to marine plants or invertebrates (Byrnes et al. 2007, Côté et al. 2013). Although the rate of introduction of fishes may be initially low, once they have been introduced they have a high potential ( $~ 50 \%)$ of becoming established, much higher than their plant counterparts for example (Jeschke and Strayer 2005). Fishes that are successful in establishing can, and usually do, have severe impacts on their invaded ecosystem through predation, most notably piscivory, which can drive population dynamics and structure the rest of the community (Hixon 2015). Invasive predators are also likely to have important nonconsumptive 'fear' effects (Mitchell and Harborne 2020), but these have rarely been investigated for tropical marine species (see Kindinger 2015, Eaton et al. 2016, Kindinger and Albins 2017 for exceptions). While several fishes have been introduced accidentally (via global trade or the aquaculture industry), others have been introduced intentionally by governmental agencies, most often with the purpose of opening new fisheries to local communities or enhance existing ones (Randall 1987) (see Additional file 1).

For the purpose of this review, we are only focusing on established NNS, but recognize that individuals of many other species have been observed in NN regions without becoming established (e.g. see Semmens et al. 2004, and Schofield and Akins 2019, for fish species seen in Florida). NN fish species that are not fully marine (brackish, anadromous) such as members of the family Cichlidae or Salmonidae that have been intentionally introduced globally (De Silva 2004, Buoro et al. 2016) are also excluded from this list. However, it should be noted that many of these species have drastic impacts on native flora/fauna and some of them are described as vectors of diseases and parasites (See Section 5). Additionally, for some species it is unclear if their non-native presence is due to introduction or is simply a natural range expansion of nearby native populations (e.g. Gramma loreto in Florida and Hypsoblennius invemar in Brazil). With the above caveats, we will focus on examples of non-native fish species that are invasive and/or those which have invasive characteristics.

Perhaps the best studied marine vertebrate NNS is the Indo-Pacific lionfish (Pterois spp.), and its invasion in the western Atlantic. Lionfish were first observed off the coast of Florida in 1985 (Schofield 2009), with a likely introduction of a few individuals from the aquarium trade (Whitfield et al. 2002, Betancur-R et al. 2011). Sightings remained low for several years until the first report of lionfish in the Bahamas occurred in 2004. This was followed by a rapid increase in abundance and range expansion throughout the Caribbean to South America (Schofield 2009). Currently, the entire non-native distribution of lionfish spans as far south as Venezuela east to Bermuda, throughout the GOM, and year-round 
northern populations persist along the coast of North Carolina (Schofield 2010, Côté and Smith 2018). The expansion of the known range of this fish in the western Atlantic can be seen at https://nas.er.usgs.gov/taxgroup/ fish/Lionfishanimation.gif. While the northwards range expansion of the lionfish in the western Atlantic may be near their thermal physiological limits (Kimball et al. 2004), their expansive invase range here and their new invasion in the Mediterranean Sea indicates that TMEs are not the only ecosystems being impacted by this NNS (Kletou et al. 2016).

There are several studies which report the negative impacts of lionfish. However, there are an equal number of contrasting studies which suggest the impact is not as clear cut as one would imagine. For example, in the Bahamas and Florida there are reports of significant declines in native prey populations (Albins and Hixon 2008, Green et al. 2012), declines in overall species richness (Albins 2013, Albins and Hixon 2013, Albins 2015, Ellis and Faletti 2016), and local extinctions of a few native species (Ingeman 2016). However, in contrast, in Venezuela and Belize, no such changes in native species abundance or richness were observed (Elise et al. 2015, Hackerott et al. 2017). In the southeast US, the decline of adult tomtate populations (Haemulon aurolineatum) has also been attributed to lionfish predating on their juvenile population (Ballew et al. 2016). However, other studies again find no such trends (i.e. no decline in specific fish populations due to losses of early life stages) (Green and Côté 2014, Albins 2015). The same appears true with competition driven by this new predator. Some studies have shown dramatic declines in native mesopredator populations (Lesser and Slattery 2011) and altered behavior of native species (Henderson 2012, Raymond et al. 2015), whilst others show no such trends (Elise et al. 2015, Ballew et al. 2016). In fact, some find that native meso-predators may actually reduce the negative impacts of the invasive alien (Ellis and Faletti 2016). Such conflicting data suggests lionfish impact native fish populations in complex speciesspecific and/or geographically distinct ways. However, the invasion may be entering a new phase in the western Atlantic. An ulcerative skin condition appears to be plaguing lionfish in their new range (Harris et al. 2020) and their densities appear to be dropping in some locations (Benkwitt et al. 2017).

Another NNS, the regal demoiselle (Neopomacentrus cyanomos) is a more recent case of invasion. Originally from the Indo-Pacific, $N$. cyanomos was reported in the GOM, near the reefs of Coatzacoalcos, Mexico in 2013 (González-Gándara and de la Cruz-Francisco 2014). Since then, it was documented to rapidly spread throughout the northern coastal region of the GOM (Robertson et al. 2016, Bennett et al. 2019). The front of the non-native region is currently near the Florida Panhandle just south of Panama City Beach (USGS NAS). In addition to the expanding distribution in the GOM, a second site of introduction was documented in Trinidad in 2019 (Robertson et al. 2021). Given the locations of introduction, the current distribution, and the density of populations at specific locations, it is hypothesized that $N$. cyanomos arrived to the Atlantic as hitchhikers on oil platforms, like how the coral Tubastraea micranthus was thought to be introduced into Brazil (Robertson et al. 2016, Robertson et al. 2021). The impacts of this NNS remain unknown, but visual observations from divers suggest that $N$. cyanomos potentially competes with and displaces native planktivores such as Chromis multilineata (González-Gándara and de la Cruz-Francisco 2014, Robertson et al. 2016).

The muzzled blenny Omobranchus punctatus, is another good example of a vertebrate NNS. Native to the Indo-Pacific, it has spread through the Caribbean and Brazil since the 1930s (Gerhardinger et al. 2006, LassoAlcalá et al. 2011, Soares et al. 2011). The proximity of most records to ports, indicate that this NNS was initially introduced to the Atlantic by ships travelling from India to Trinidad and then into Brazil by shipping associated with oil platforms (Lasso-Alcalá et al. 2011) - a similar theme to the introductions reported above.

Although never intended for introduction into natural habitats, incidences of non-native fish species escaping mariculture facilities are an all too common occurrence and a major source of NNS. In Singapore for example, non-native fishes procured by the Agri-Food and Veterinary Authority (now Singapore Food Authority) such as Chanos chanos, Sciaenops ocellatus, and Larimichthys crocea have been recorded as escapees and established populations off the coast (Jaafar et al. 2012). The cobia, Rachycentron canadum, is yet another example. This circum-global tropical and sub-tropical species is a highly valued food fish reared in floating cages worldwide (Benetti et al. 2010). In 2015, cages were installed off the coast of Ecuador, a region lacking native populations. Several months after, the Ecuadorian Ministry of Environment reported that individuals escaped from one of these cages. Local fishermen have reported catching some of these escapees (Castellanos-Galindo et al. 2016). This NNS has since been discovered off the coasts of Colombia, Peru, and Panama, within only a few months after the initial recorded escape (Vega et al. 2016). The potential impacts of this species on the native biota are yet unexplored. However, this predatory NNS reaches sexual maturity early, is highly fecund, and resides in a variety of coastal habitats, suggesting a high potential to disrupt the native TMEs of the Tropical Eastern Pacific (CastellanosGalindo et al. 2018). 
The opening of the Panama Canal in 1914 is also worthy of briefly mentioning here as it is a major pathway for NNS invasions (Gunter 1979, Cohen 2006). While most of these NNS are confined to the lakes within the canal system (McCosker and Dawson 1975), and will therefore not be discussed in this review, there is one $\mathrm{NN}$ fish that crossed from the Atlantic to the Pacific. The Atlantic tarpon (Megalops atlanticus) now has stable populations in the Tropical Eastern Pacific, with an expanding distribution. Hildebrand (1937) first described their presence in the lakes near the Pacific entrance of the canal in the 1930s. This was followed by Swanson's (1946) observation of tarpon outside the entrance. Currently their distribution in the Pacific ranges from Guatemala to the border of Colombia and Ecuador (Cohen 2006, Castellanos-Galindo et al. 2019). While the impacts of the tarpon introduction to the Tropical Eastern Pacific are unknown, their trophic status suggests potential negative effects on native prey communities (Castellanos-Galindo et al. 2019).

Although many of the previous examples were the results of accidental introductions, intentional introductions have also occurred in several cases. In the 1950s, the Division of Fish and Game of the State of Hawai' $i$ intentionally introduced several marine fish species into the wild either to increase the diversity of local reef fish communities or to open new fisheries. One such event was the introduction of Sardinella marquesensis from the Marquesas Islands to O'ahu in 1955, initially intended to provide bait for tuna. Although established, the abundance of $S$. marquesensis remains relatively low compared to native and other invasive baitfish species (see below; Randall 1987). In addition, the vessels that transported $S$. marquesensis to $\mathrm{O}^{\prime}$ ahu unintentionally contained several other species, including two NNS (Osteomugil engeli -previousely known as Valamugil engeli- and Upeneus vittatus; Randall 1987, Mundy 2005). Both have since become established, but only $O$. engeli has populations in high abundance with the potential to compete with native species, such as the commercially important mullet species Mugil cephalus (Randall 1987). Interestingly another NNS (Herklotsichthys quadrimaculatus), which was also unintentionally introduced to Hawai'i in 1975 (likely brought over by tuna fishing vessels returning from the Marshall Islands) (Baldwin 1984, Randall 1987, Mundy 2005) appears to have been the cause for the low abundances of $S$. marquesensis (as well as other native baitfish species).

Another event of intentional introduction in Hawai' $i$ included members of the families Lutjanidae, Lethrinidae, and Serranidae. In the 1950s, eleven species were released and three became established (Randall 1987, Mundy 2005): Cephalopholis argus and Lutjanus fulvus from Moorea and Lutjanus kasmira from the
Marquesas. Unlike L. fulvus populations that remain relatively low, L. kasmira is highly abundant. The latter species has invaded the entire Hawaiian archipelago, all islands in both the Main Hawaiian Islands and the Northwestern Hawaiian Islands. It is perceived to reduce catches of more valuable native species and potentially compete with and displace native species (Randall 1987, Oda and Parrish 1981, Friedlander et al. 2002, Schumacher and Parrish 2005). That said, C. argus has received more research attention than the two snapper species due to possible human health concerns. After the initial release of this NNS, there was a considerable lag time before reaching substantial populations in the 1980s (Crooks 2005). Once populations were high, there was renewed interest in establishing a fishery around this species. That was until reports of ciguatera poisoning in humans arose after their consumption (Dierking and Campora 2009). Despite only $18.2 \%$ of $C$. argus individuals having toxins high enough to be harmful to humans (Dierking and Campora 2009), the concern of poisoning has essentially closed the fishery. Populations of this piscisvorous species are now unchecked and have the potential to impact the native prey communities (Dierking et al. 2009).

\section{Non-native diseases in tropical marine ecosystems}

Disease-causing organisms (parasites and pathogens) are common in all ecosystems and cause a plethora of diseases in various species (Groner et al. 2016, Harvell 2019). Introductions of NNS has been accredited as being a major way to either directly or indirectly modulate the normal interplay between parasites and their hosts, and could serve as one of the main drivers of novel emerging diseases in TMEs, ultimately affecting biodiversity, ecosystem function and ecosystem services/human health (Crowl et al. 2008, Goedknegt et al. 2016; see also Torchin et al. 2002, Blakeslee et al. 2013). In this final section of the review, we exclusively focus on diseases that have been shown to be caused by NNS (either through introducing a NN host or a NN parasite). For the sake of this review, we are defining parasites as 'organisms living on or in another organism, deriving substances from the host organism, without benefit to the host'. We are therefore using this broad definition including parasitoids and other pathogens (disease-causing organisms) that ultimately produce damage in the host (Prenter et al. 2004).

Any NNS, when first introduced would always have the potential of carrying its natural parasite load with it. During the 'invasion' process, this load could be released or significantly reduced in number (Lymbery et al. 2014, Goedknegt et al. 2016). However, if only a few of these parasites make the journey with the host NNS, they are likely to parasitise new hosts which would likely be more 
susceptible to these new disease causing organisms (Vignon and Sasal 2010, Lymbery et al. 2014). Farmed escapees are likely the main group of NNS which will carry and spread the highest number of their parasites into any new range. For instance, NN shrimps brought to a given country for aquaculture practices (such as Penaeus monodon and Penaeus vannamei) have been known to carry several viral pathogens such as monodon baculovirus (MBV), infectious hypodermal and hematopoietic necrosis virus (IHHNV), hepatopancreatic parvovirus (HPV), and taura syndrome virus (TSV) (O'Connor et al. 2008, Hernández 2020; for more detail about shrimp diseases see Briggs et al. 2004 and Sweet and Bateman 2016). It has been hypothesized that these viruses could easily transmit to native shrimp populations, especially if the aquaculture farms are 'open' to the sea (Briggs et al. 2004, Walker and Mohan 2009, Sweet and Bateman 2016).

In other cases, a NNS can exhibit a depauperate ensemble of parasites in its introduced region. For example, the coexistence of gill ectoparasites (such as copepods and monogeans) have been found to be associated with the peacock grouper, Cephalopholis argus, in its native range (Lo et al. 2001) while comparative parasitological studies have shown that $C$. argus loses a significant amount of its native metazoan parasite community when introduced into new areas (Hawai i for example, see section 4) (Vignon et al. 2009).

NNS may also play a role as reservoirs for native parasites, increasing their abundance and possible impact (Prenter et al. 2004). That said, these native parasites may well limit the demographic performance of a NNS (Sellers et al. 2015b, Goedknegt et al. 2016). For example, as discussed above the with regard to the lionfish (Pterois spp.), they now appear to be acquiring new parasites within their invaded range (see section 4 ). In this example, this NNS may be more susceptible to parasites due to its unnaturally high population densities and low genetic diversity - all common traits in the NNS discussed throughout this review. Ulcerative Skin Disease was only reported to affect lionfish in 2017 and may be why we are starting to see declines in this NNS across parts of its invaded range (Harris et al. 2018, 2020). That said, there is also another negative impact this hostparasite interaction may yield, i.e. that of parasite spillback. This is when native parasites cause mass infections in an NNS, and then subsequently the parasite transmits back to the native host population causing an increase in disease amongst native hosts (Harris et al. 2020).

Alternaively if invasive parasites are co-introduced with their invasive host and then subsequently transmit to local native species this is referred to as parasite spillover (Goedknegt et al. 2016). The bluestripe snapper (Lutjanus kasmira) (see section 4) has been shown to carry an intestinal nematode (Spirocamallanus istiblenni), which can 'spill over' to native Hawaiian fishes for example (Gaither et al. 2013).

It is also possible for $\mathrm{NN}$ parasites to arrive independent of their host. This is primarily via a vector such as ballast water (Goedknegt et al. 2016). It is very difficult to identify when an ecosystem is invaded by a NN parasite species, but the rapid regional spread of a newly identified disease within a specific group of animals could highlight the likelihood of this happening. An example is the mass die-off of the tropical sea urchin Diadema antillarum in the Western Atlantic (Lessios et al. 1984, Lessios 1988). A similar disease, this time affecting Echinothrix calimaris and Diadema paucispinum, also occurred in Hawaii around the same time (1981). In both these cases, the causal agent or agensts was not known, yet the disease/s was thought to originate near the Caribbean entrance to the Panama Canal suggesting both might be related or even the same (Birkeland 1989).

Another example is the newly observed coral disease in Florida, dubbed 'stony coral tissue loss disease' (or SCTLD). This disease impacts many coral species and is particularly virulent, spreading north and south of its reported origin (Florida) (Aeby et al. 2019, Precht et al. 2016) and is now being reported across much of the Caribbean. Ballast water has again been highlighted as a possible cause of the rapid spread (U.S. Coast Guard 2019, Sweet et al. 2021). There is therefore real concern that the parasite(s) (again as of yet unknown origin), could be transported through the Panama Canal from the Atlantic and into the Indo-Pacific in the not-sodistant future. If such a hypothesis came true, this would be a clear example of the high potential for many more parasites to warrant classification as NNS.

Although it is likely that every NNS carries with it some form of parasite, information on this topic remains scarce. This is primarily due to the difficulties in detecting and identifying these organisms. Further, many parasites are likely to be cryptogenic and their impact would almost always go undetected in short-term studies (Gaither et al. 2013, Lohan et al. 2020). This is certainly an important area for future research and will be paramount in assessing the true impact NNS have on their new habitats. Further, survival of these NN parasites will likely be dependant on the survival and success of the original host, the host specificity of the parasite and the ability (or not) of the parasite to produce a resting or dormant stage (see Torchin et al. 2002, Lohan et al. 2020).

\section{Conclusion}

Non-native species are an integral component of marine tropical ecosystems. NNS have been introduced to the tropical waters, deliberately and incidentally, and some of them have become established, invaded other areas, 
and caused detrimental ecological impacts, examples of which we give in this review. Such impacts mostly occur through competition, predation, habitat alteration, and disease. However, knowledge of the extent of impacts NNS have on native biota and ecosystems remain incomplete (e.g. see Lesser and Slattery 2011). This is primarily because many NNS are inconspicuous or difficult to identify or locate.

It was evident when compiling this review that Hawai i stood out as being heavily impacted by NNS (see Additional file 2). Whether this is because of its location, governance or the level of research undertaken to understand NNS in this region we can not tease apart. One factor may be the lower native biodiversity associated with Hawaiian ecosystems (Hutchings et al. 2002). Indeed, areas with higher biodiversity have been shown to be less susceptible (in general) to invasions by NNS (Kühn and Klotz 2008, Wells and Bieler 2020). This is primarily due to fewer vacant niches being available to the NSS (Hewitt 2002, Kennedy et al. 2002). Therefore, we may very well witness a rise in the number of NNS which become established in TMEs when the results of regional anthropogenic impacts and global climate change occur i.e. declines in the native flora and fauna (Occhipinti-Ambrogi 2007, Worm and Lotze 2016). Therefore, there is an urgent need to first gain a better understanding of the species already present in any given TME i.e. a detailed baseline survey conducted across space and time. This will allow us to detect when a new NNS is introduced to a given area and explore invasion pathways more reliably. Armed with this knowledge we may even be able to mitigate and manage the impacts from newly emerging NNS before they become established and uncontrollable. Although several countries are indeed taking an active stance in creating inventories of NNS, many (especially in the Indo-Pacific) are less diligent.

\section{Supplementary Information}

The online version contains supplementary material available at https:/doi. org/10.1186/s41200-021-00206-8

Additional file 1. A list of marine non-native species in tropical regions (including Tropical Atlantic, Indo-Pacific and Tropical Eastern Pacific).

Additional file 2. Reference list for Additional file 1, plus additional table and figures.

\section{Acknowledgements}

The authors are grateful to Dr. John Bishop (Associate Editor of MBIR) and three anonymous reviewers for the valuable comments and suggestions which helped to improve the manuscript.

\section{Authors' contributions}

All authors contributed to the writing the related sections, and revision of the manuscript and approved the final manuscript.
Funding

Not applicable.

Availability of data and materials

All data generated or analysed during this study are included in this published article [supplementary information: Additional files 1 and 2].

\section{Declarations}

Ethics approval and consent to participate

Not applicable.

Consent for publication

Not applicable.

\section{Competing interests}

The authors declare that they have no competing interests. The findings and conclusions in this article are those of the author(s) and do not necessarily represent the views of the U.S. Fish and Wildlife Service.

\section{Author details}

${ }^{1}$ Department of Marine Biology, Science and Research Branch, Azad University, Tehran, Iran. ²Departamento de Ecologia, Laboratório de Ecologia Marinha Bêntica, IBRAG, Universidade do Estado do Rio de Janeiro, Rua São Francisco Xavier, 524, PHLC, sala 220, Maracanã, CEP 20550-900, Rio de Janeiro, RJ, Brazil. ${ }^{3}$ Institute of Environment and Department of Biological Sciences, Florida International University, 3000 NE 151st Street, North Miami, FL 33181, USA. ${ }^{4}$ NOAA Contractor, PO Box 7390, Pago Pago, AS 96799, USA ${ }^{5}$ Department of Biological Sciences, 14 Science Drive 4, National University of Singapore, Singapore 117558, Singapore. ${ }^{6} \mathrm{AECOM}$, Impact Assessment and Planning, 7650 West Courtney Campbell Causeway, Tampa, Florida 33607, USA. ${ }^{7}$ Marine Biologist, Pacific Islands Fish and Wildlife Office, U.S. Fish and Wildlife Service, 300 Ala Moana Blvd. Rm 3-122, 808-792-9456, Honolulu HI96815, USA. ${ }^{8}$ Suganthi Devadason Marine Research Institute, Tuticorin, India. ${ }^{9}$ Aquatic Research Facility, Environmental Sustainability Research Centre, University of Derby, Derby, UK

Received: 2 June 2020 Accepted: 2 April 2021

Published online: 23 April 2021

\section{References}

Aeby GS, Ushijima B, Campbell JE, Jones S, Williams GJ, Meyer JL, et al. Pathogenesis of a tissue loss disease affecting multiple species of corals along the Florida Reef Tract. Front Mar Sci. 2019;6:678.

Albins MA. Effects of invasive Pacific red lionfish Pterois volitans versus a native predator on Bahamian coral-reef fish communities. Biol Invasions. 2013;15(1): 29-43.

Albins MA. Invasive Pacific lionfish Pterois volitans reduce abundance and species richness of native Bahamian coral-reef fishes. Mar Ecol Prog Ser. 2015;522: 231-43.

Albins MA, Hixon MA. Invasive Indo-Pacific lionfish Pterois volitans reduce recruitment of Atlantic coral-reef fishes. Mar Ecol Prog Ser. 2008;367:233-8.

Albins MA, Hixon MA. Worst case scenario: potential long-term effects of invasive predatory lionfish (Pterois volitans) on Atlantic and Caribbean coral-reef communities. Environ Biol Fish. 2013;96(10-11):1151-7.

Ali HA, Sivakumar V, Tamilselvi M. Distribution of alien and cryptogenic ascidians along the Southern Coasts of Indian Peninsula. World. 2009:1(4):305-12.

Allais JR, Amaro ME, McFadden CS, Halász A, Benayahu Y. The first incidence of an alien soft coral of the family Xeniidae in the Caribbean, an invasion in eastern Venezuelan coral communities. Coral Reefs. 2014;33(2):287.

Allen J. Mangroves as alien species: the case of Hawai'i. Glob Ecol Biogeogr Lett. 1998;7(1):61-71.

Altvater L, Coutinho R. Colonisation, competitive ability and influence of Stragulum bicolor van Ofwegen and Haddad, 2011 (Cnidaria, Anthozoa) on the fouling community in Paranaguá Bay, Southern Brazil. J Exp Mar Biol Ecol. 2015:462:55-61.

Anderson LG, Rocliffe S, Haddaway NR, Dunn AM. The role of tourism and recreation in the spread of non-native species: a systematic review and meta-analysis. PLoS One. 2015;10(10). 
Ask El, Batibasaga A, Zertuche-Gonzalez JA, De San M. Three decades of Kappaphycus alvarezii (Rhodophyta) introduction to non-endemic locations. Procedi Int Seaweed Symposium. 2003;17:49-57.

Ávila E, Carballo JL. A preliminary assessment of the invasiveness of the IndoPacific sponge Chalinula nematifera on coral communities from the tropical Eastern Pacific. Biol Invasions. 2009;11(2):257-64.

Baldwin WJ. A Note on the Occurrence of the Gold Spot Herring, Herklotsichthys quadrimaculatus (Ruppell) in Hawai'i. Pac Sci. 1984;38(2):123-6.

Ballew NG, Bacheler NM, Kellison GT, Schueller AM. Invasive lionfish reduce native fish abundance on a regional scale. Sci Rep. 2016;6:32169.

Barbier EB. Marine ecosystem services. Curr Biol. 2017;27(11):R507-10.

Barbier EB, Hacker SD, Kennedy C, Koch EW, Stier AC, Silliman BR. The value of estuarine and coastal ecosystem services. Ecol Monogr. 2011;81(2): 169-93.

Barnhill KA, Bahr KD. Coral Resilience at Malaukaa Fringing Reef, Kāne‘ohe Bay, O‘ahu after 18 years. J Marine Sci Eng. 2019;7(9):311.

Bax N, Williamson A, Aguero M, Gonzalez E, Geeves W. Marine invasive alien species: a threat to global biodiversity. Mar Policy. 2003;27(4):313-23.

Becking LE, van Bussel TC, Debrot AO, Christianen MJ. First record of a Caribbean green turtle (Chelonia mydas) grazing on invasive seagrass (Halophila stipulacea). Caribb J Sci. 2014;48(2-3):162-3.

Benetti DD, O'Hanlon B, Rivera JA, Welch AW, Maxey C, Orhun MR. Growth rates of cobia (Rachycentron canadum) cultured in open ocean submerged cages in the Caribbean. Aquaculture. 2010;302(3-4):195-201.

Benkwitt CE, Albins MA, Buch KL, Ingeman KE, Kindinger TL, Pusack TJ, et al. Is the lionfish invasion waning? Evidence from The Bahamas. Coral Reefs. 2017; 36(4):1255-61.

Bennett CT, Robertson A, Patterson WF III. First record of the non-indigenous Indo-Pacific damselfish, Neopomacentrus cyanomos (Bleeker, 1856) in the northern Gulf of Mexico. Biolnvasions Record. 2019;8(1).

Bernier RY, Locke A, Hanson JM. Lobsters and crabs as potential vectors for tunicate dispersal in the southern Gulf of St. Lawrence, Canada. Aquat Invasions. 2009;4(1):105-10.

Betancur-R R, Hines A, Acero PA, Ortí G, Wilbur AE, Freshwater DW. Reconstructing the lionfish invasion: insights into Greater Caribbean biogeography. J Biogeogr. 2011;38(7):1281-93.

Birkeland C. The influence of echinoderms on coral-reef communities. Echinoderm Stud. 1989;3:1-79.

Bixler HJ. Recent developments in manufacturing and marketing carrageenan. In: Fifteenth International Seaweed Symposium. Dordrecht: Springer; 1996.

Blakeslee AM, Fowler AE, Keogh CL. Marine invasions and parasite escape: updates and new perspectives. Adv Mar Biol. 2013;66:87-169.

Boman EM, Bervoets T, De Graaf M, Dewenter J, Maitz A, Zu Schlochtern MP, et al. Diet and growth of juvenile queen conch Lobatus gigas (Gastropoda: Strombidae) in native, mixed and invasive seagrass habitats. Mar Ecol Prog Ser. 2019;621:143-54.

Briggs M, Funge-Smith S, Subasinghe R, Phillips M. Introductions and movement of Penaeus vannamei and Penaeus stylirostris in Asia and the Pacific. RAP Publication. 2004;10(2004):92.

Budd AF, Guzma'n HM. Siderastrea glynni, a new species of scleractinian coral (Cnidaria:Anthozoa) from the eastern Pacific. In: Proceedings of the Biological Society of Washington, vol. 107; 1994. p. 591-9.

Buddo DS, Steele RD, D'Oyen ER. Distribution of the invasive Indo-Pacific green mussel, Perna viridis, in Kingston Harbour, Jamaica. Bull Mar Sci. 2003;73(2): 433-41.

Buoro M, Olden JD, Cucherousset J. Global Salmonidae introductions reveal stronger ecological effects of changing intraspecific compared to interspecific diversity. Ecol Lett. 2016;19(11):1363-71.

Bush SL, Precht WF, Woodley JD, Bruno JF. Indo-Pacific mushroom corals found on Jamaican reefs. Coral Reefs. 2004;23(2):234.

Byrnes JE, Reynolds PL, Stachowicz JJ. Invasions and extinctions reshape coastal marine food webs. PLoS One. 2007;2(3).

Cagauan AG. Exotic aquatic species introduction in the Philippines for aquaculture-A threat to biodiversity or a boom to the economy. J Environ Sci Manage. 2007;10(1):48-62.

Cairns SD, Zibrowius H. Cnidaria Anthozoa: azooxanthellate Scleractinia from the Philippine and Indonesian regions. Mémoires du Muséum national d'Histoire naturelle. 1997:172:27-243.

Capel KC, Creed J, Kitahara MV, Chen CA, Zilberberg C. Multiple introductions and secondary dispersion of Tubastraea spp. in the Southwestern Atlantic. Sci Rep. 2019;9(1):1-1.
Capel KC, Creed JC, Kitahara MV. Invasive corals trigger seascape changes in the southwestern Atlantic. Bull Mar Sci. 2020;96(1):2017-8.

Capel KC, Toonen RJ, Rachid CT, Creed JC, Kitahara MV, Forsman Z, et al. Clone wars: asexual reproduction dominates in the invasive range of Tubastraea spp. (Anthozoa: Scleractinia) in the South-Atlantic Ocean. PeerJ. 2017:5:e3873.

Carballo JL, Aguilar-Camacho JM, Knapp IS, Bell JJ. Wide distributional range of marine sponges along the Pacific Ocean. Mar Biol Res. 2013;9(8):768-75.

Carlton JT. Deep invasion ecology and the assembly of communities in historical time. In: Rilov G, Crooks JA, editors. Biological invasions in marine ecosystems. Ecological Studies (Analysis and Synthesis). Berlin: Springer; 2009. https://doi.org/10.1007/978-3-540-79236-9_2.

Carlton JT, Eldredge LG. Marine bioinvasions of Hawai'i. In: Bernice P, editor. : Bishop Museum/Bishop Museum Press; 2009.

Carlton JT, Eldredge LG. Update and revisions of the marine bioinvasions of Hawai'i:The introduced and cryptogenic marine and estuarine animals and plants of the Hawaiian archipelago. Lucius G. Eldredge III Memorial Volume: Tribute to a Polymath. Bishop Museum Bull Zool. 2015;9:25-47.

Carpinelli AN, Cordeiro RT, Neves LM, De Moura RL, Kitahara MV. Erythropodium caribaeorum (Duchassaing and Michelotti, 1860) (Cnidaria: Alcyonacea), an additional alien coral in the Southwestern Atlantic. Zootaxa. 2020;4822(2): 175-90.

Castellanos-Galindo G, Baos R, Zapata L. Mariculture-induced introduction of cobia Rachycentron canadum (Linnaeus, 1766), a large predatory fish, in the Tropical Eastern Pacific. Biolnvasions Records. 2016;5(1):55-8.

Castellanos-Galindo G, Moreno X, Robertson R. Risks to eastern Pacific marine ecosystems from sea-cage mariculture of alien Cobia. Manage Biol Invasions. 2018;9(3):323-7.

Castellanos-Galindo GA, Robertson DR, Pacheco-Chaves B, Angulo A, ChongMontenegro C. Atlantic Tarpon in the Tropical Eastern Pacific 80 years after it first crossed the Panama Canal. Rev Fish Biol Fish. 2019;29(2):401-16.

Chandrasekaran S, Nagendran NA, Pandiaraja D, Krishnankutty N, Kamalakannan B. Bioinvasion of Kappaphycus alvarezii on corals in the Gulf of Mannar, India. Curr Sci. 2008:1167-72.

Chimner RA, Fry B, Kaneshiro MY, Cormier N. Current Extent and Historical Expansion of Introduced Mangroves on O'ahu, Hawai'i. Pac Sci. 2006;60(3): 377-83.

Chiquillo KL, Barber PH, Willette DA. Fruits and flowers of the invasive seagrass Halophila stipulacea in the Caribbean Sea. Bot Mar. 2019;62(2):109-12.

Christianen MJ, Smulders FO, Engel MS, Nava MI, Willis S, Debrot AO, et al. Megaherbivores may impact expansion of invasive seagrass in the Caribbean. J Ecol. 2019;107(1):45-57.

Claydon JA, Calosso MC, Traiger SB. Progression of invasive lionfish in seagrass, mangrove and reef habitats. Mar Ecol Prog Ser. 2012;448:119-29.

Cohen AN. Chapter III Species Introductions and the Panama Canal. In: Gollasch S., Galil B.S., Cohen A.N. (eds) Bridging Divides. Springer, Dordrecht. 2006. https://doi.org/10.1007/978-1-4020-5047-3_5.

Coles SL, Bolick H. Invasive introduced sponge Mycale grandis overgrows reef corals in Kāne'ohe Bay, O 'ahu, Hawai'i. Coral Reefs. 2007;26(4):911.

Coles SL, Marchetti J, Bolick H, Montgomery A. Assessment of invasiveness of the orange keyhole sponge Mycale armata in Kāne'ohe Bay, O 'ahu, Hawai'l (Final Report, 2). Bishop Museum Technical Report. 2007:2006-2.

Collins K, Keith I, Dawson TP. Countering the threat of invasive species to the Galapagos marine reserve. Marine Protected Areas. 2020:285-98. https://doi. org/10.1016/B978-0-08-102698-4.00015-0.

Concepcion GT, Kahng SE, Crepeau MW, Franklin EC, Coles SL, Toonen RJ. Resolving natural ranges and marine invasions in a globally distributed octocoral (genus Carijoa). Mar Ecol Prog Ser. 2010;401:113-27.

Conklin EJ, Smith JE. Abundance and spread of the invasive red algae, Kappaphycus spp., in Kāne'ohe Bay, Hawai'i and an experimental assessment of management options. Biol Invasions. 2005;7(6):1029-39.

Côté IM, Green SJ, Hixon MA. Predatory fish invaders: insights from IndoPacific lionfish in the western Atlantic and Caribbean. Biol Conserv. 2013; 164:50-61.

Côté IM, Smith NS. The lionfish Pterois sp. invasion: Has the worst-case scenario come to pass? J Fish Biol. 2018;92(3):660-89.

Creed JC. Two invasive alien azooxanthellate corals, Tubastraea coccinea and Tubastraea tagusensis, dominate the native zooxanthellate Mussismilia hispida in Brazil. Coral Reefs. 2006;25(3):350.

Creed JC, Fenner D, Sammarco P, Cairns S, Capel K, Junqueira AO, et al. The invasion of the azooxanthellate coral Tubastraea (Scleractinia: 
Dendrophylliidae) throughout the world: history, pathways and vectors. Biol Invasions. 2017a; 19(1):283-305.

Creed JC, Junqueira AD, Fleury BG, Mantelatto MC, Oigman-Pszczol SS. The SunCoral Project: the first social-environmental initiative to manage the biological invasion of Tubastraea spp. in Brazil. Manage Biol Invasions. 2017b; 8(2):181

Crooks JA. Lag times and exotic species: The ecology and management of biological invasions in slow-motion1. Ecoscience. 2005;12(3):316-29.

Crowl TA, Crist TO, Parmenter RR, Belovsky G, Lugo AE. The spread of invasive species and infectious disease as drivers of ecosystem change. Front Ecol Environ. 2008;6(5):238-46.

Davidson AD, Campbell ML, Hewitt CL, Schaffelke B. Assessing the impacts of nonindigenous marine macroalgae: an update of current knowledge. Bot Mar. 2015;58(2):55-79.

de Faria LC, Kitahara MV. Invasive corals hitchhiking in the Southwestern Atlantic. Ecology. 2020:e03066.

de Oliveira Soares M, Davis M, de Macêdo Carneiro PB. Northward range expansion of the invasive coral (Tubastraea tagusensis) in the southwestern Atlantic. Mar Biodivers. 2018;48(3):1651-4.

De Paula AF, Creed JC. Two species of the coral Tubastraea (Cnidaria, Scleractinia) in Brazil: a case of accidental introduction. Bull Mar Sci. 2004;74(1):175-83.

De Paula AF, de Oliveira PD, Creed JC. Reproductive strategies of two invasive sun corals (Tubastraea spp.) in the southwestern Atlantic. J Mar Biol Assoc U K. 2014;94(3):481-92.

De Paula AF, Fleury BG, Lages BG, Creed JC. Experimental evaluation of the effects of management of invasive corals on native communities. Mar Ecol Prog Ser. 2017;572:141-54

De Poorter M, Darby C, MacKay J. Marine Menace: alien invasive species in the marine environment. Gland: IUCN; 2009. p. 30.

De Silva SS. Tilapias as alien aquatics in Asia and the Pacific: a review. Food Agric Org 2004.

De Silva SS, Nguyen TT, Turchini GM, Amarasinghe US, Abery NW. Alien species in aquaculture and biodiversity: a paradox in food production. Ambio. 2009, 38(1):24-8. 19260343. https://doi.org/10.1579/0044-7447-38.1.24.

Demopoulos AW, Fry B, Smith CR. Food web structure in exotic and native mangroves: a Hawai'i -Puerto Rico comparison. Oecologia. 2007;153(3): $675-86$.

Demopoulos AW, Smith CR. Invasive mangroves alter macrofaunal community structure and facilitate opportunistic exotics. Mar Ecol Prog Ser. 2010:404:51-67.

Den Hartog C. The sea-grasses of the world. North-Holland, Amsterdam; 1970.

Dierking J, Campora CE. Ciguatera in the Introduced Fish Cephalopholis argus (Serranidae) in Hawai'i and Implications for Fishery Management1. Pac Sci. 2009:2:193-204

Dierking J, Williams ID, Walsh WJ. Diet composition and prey selection of the introduced grouper species peacock hind (Cephalopholis argus) in Hawai'. Fish Bull. 2009;107(4):464-76.

dos Santos LA, Ribeiro FV, Creed JC. Antagonism between invasive pest corals Tubastraea spp. and the native reef-builder Mussismilia hispida in the southwest Atlantic. J Exp Mar Biol Ecol. 2013;449:69-76.

Dubinsky Z, Stambler N, editors. Coral reefs: an ecosystem in transition. Springe Science \& Business Media; 2010. e-ISBN 978-94-007-0114-4.

Eaton L, Sloman KA, Wilson RW, Gill AB, Harborne AR. Non-consumptive effects of native and invasive predators on juvenile Caribbean parrotfish. Environ Biol Fish. 2016:99(5):499-508.

Edward JKP, Bhatt JR. A note on bio-invasion of Kappaphycus alvarezii on coral reefs and seagrass beds in the Gulf of Mannar and Palk Bay. In: Bhatt JR, Edward JKP, Maclntosh D, Nilaratna BP, editors. IUCN-India; 2012. p. 281-7.

Edward JKP, Mathews G, Raj KD, Rajesh S, Arasamuthu A, Laju RL. Invasion of the exotic seaweed, Kappaphycus alvarezii, on coral areas in two islands (Krusadai \& Mulli) in the Gulf of annar, Southeastern India - status and control measures. Reef Encounter. 2015;30(2):50-3.

Eldredge LG, Smith CM. A guidebook of introduced marine species in Hawai'i: Bishop Museum Technical Report; 2001. p. 21

Elise S, Urbina-Barreto I, Boadas-Gil H, Galindo-Vivas M, Kulbicki M. No detectable effect of lionfish (Pterois volitans and P. miles) invasion on a healthy reef fish assemblage in Archipelago Los Roques National Park, Venezuela. Mar Biol. 2015:162(2):319-30

Ellis RD, Faletti ME. Native grouper indirectly ameliorates the negative effects of invasive lionfish. Mar Ecol Prog Ser. 2016;558:267-79.
Evans EC III, Buske NL, Grovhoug JG, Guinther EB, Jokiel PL. Pearl Harbor biological survey: Naval Undersea Center San Diego CA; 1974.

Farrapeira CM. The introduction of the bryozoan Zoobotryon verticillatum (Della Chiaje, 1822) in northeast of Brazil: a cause for concern. Biol Invasions. 2011; 13(1):13-6

Fenner D. New observations on the stony coral (Scleractinia, Milleporidae, and Stylasteridae) species of Belize (Central America) and Cozumel (Mexico). Bull Mar Sci. 1999;64(1):143-54.

Fenner D. Biogeography of three Caribbean corals (Scleractinia) and the invasion of Tubastraea coccinea into the Gulf of Mexico. Bull Mar Sci. 2001;69(3):1175-89.

Fenner D, Banks K. Orange cup coral Tubastraea coccinea invades Florida and the Flower Garden Banks, northwestern Gulf of Mexico. Coral Reefs. 2004;23(4): 505-7.

Ferreira CE, Gonçalves JE, Coutinho R. Ship hulls and oil platforms as potential vectors to marine species introduction. J Coast Res. 2006:1340-5.

Ferreira CE, Junqueira AD, Villac MC, Lopes RM. Marine bioinvasions in the Brazilian coast: brief report on history of events, vectors, ecology, impacts and management of non-indigenous species. In: Rilov G, Crooks JA, editors. Biological Invasions in Marine Ecosystems. Ecological Studies (Analysis and Synthesis): Springer, Berlin, Heidelberg; 2009. https://doi.org/10.1007/978-3-54 0-79236-9 27.

Ferry R, Buske Y, Poupin J, Smith-Ravin J. First record of the invasive swimming crab Charybdis hellerii (A. Milne Edwards, 1867) (Crustacea, Portunidae) off Martinique, French Lesser Antilles. Biolnvasions Record. 2017;6(3).

Figueroa DF, McClure A, Figueroa NJ, Hicks DW. Hiding in plain sight: invasive coral Tubastraea tagusensis (Scleractinia: Hexacorallia) in the Gulf of Mexico. Coral Reefs. 2019;38(3):395-403.

Fleury BG, Lages BG, Barbosa JP, Kaiser CR, Pinto AC. New hemiketal steroid from the introduced soft coral Chromonephthea braziliensis is a chemical defense against predatory fishes. J Chem Ecol. 2008;34(8):987-93.

Fourqurean JW, Smith TJ, Possley J, Collins TM, Lee D, Namoff S. Are mangroves in the tropical Atlantic ripe for invasion? Exotic mangrove trees in the forests of South Florida. Biol Invasions. 2010;12(8):2509-22.

Friedlander AM, Ballesteros E, Fay M, Sala E. Marine communities on oil platforms in Gabon, West Africa: high biodiversity oases in a low biodiversity environment. PLoS One. 2014;9:8.

Friedlander M, Parrish JD, DeFelice RC. Ecology of the introduced snapper Lutjanus kasmiva (Forsskal) in the reef fish assemblage of a Hawailian bay. J Fish Biol. 2002;60(1):28-48

Gaither MR, Aeby G, Vignon M, Meguro Yl, Rigby M, Runyon C, et al. An invasive fish and the time-lagged spread of its parasite across the Hawaiian archipelago. PLoS One. 2013;8(2):e56940.

Galil BS, Gevili R. Zoobotryon verticillatum (Bryozoa: Ctenostomatida: Vesiculariidae), a new occurrence on the Mediterranean coast of Israel. Marine Biodiversity Records. 2014:7.

Gambi MC, Barbieri F, Bianchi CN. New record of the alien seagrass Halophila stipulacea (Hydrocharitaceae) in the western Mediterranean: a further clue to changing Mediterranean Sea biogeography. Marine Biodiversity Records. 2009:2.

Gerhardinger LC, Freitas MO, Andrade ÁB, Rangel CA. Omobranchus punctatus (Teleostei: Blenniidae), an exotic blenny in the Southwestern Atlantic. Biol Invasions. 2006;8(4):941-6.

Glenn EP, Doty MS. Growth of the seaweeds Kappaphycus alvarezii, K. striatum and Eucheuma denticulatum as affected by environment in Hawai'i. Aquaculture. 1990;84(3-4):245-55.

Glynn PW, Grassian B, Kleemann KH, Maté JL. The true identity of Siderastrea glynni Budd \& Guzmán, 1994, a highly endangered eastern Pacific scleractinian coral. Coral Reefs. 2016:35(4):1399-404.

Glynn PW, Wellington GM. Corals and coral reefs of the Galápagos Islands: University of California Press; 1983.

Godwin LS. Hull fouling of maritime vessels as a pathway for marine species invasions to the Hawai'i an Islands. Biofouling. 2003;19(S1):123-31.

Goedknegt MA, Feis ME, Wegner KM, Luttikhuizen PC, Buschbaum C, Camphuysen KC, et al. Parasites and marine invasions: Ecological and evolutionary perspectives. J Sea Res. 2016;113:11-27.

González-Gándara C, de la Cruz-Francisco V. Unusual record of the Indo-Pacific pomacentrid Neopomacentrus cyanomos (Bleeker, 1856) on coral reefs of the Gulf of Mexico. Biolnvasions Records. 2014;3(1):49-52.

Goodenough AE. Are the ecological impacts of alien species misrepresented? A review of the "native good, alien bad" philosophy. Commun Ecol. 2010;11(1):13-21. 
Green SJ, Akins JL, Maljković A, Côté IM. Invasive lionfish drive Atlantic coral reef fish declines. PLoS One. 2012;7(3).

Green SJ, Côté IM. Trait-based diet selection: prey behaviour and morphology predict vulnerability to predation in reef fish communities. J Anim Ecol. 2014 83(6):1451-60.

Grigg RW. Invasion of a deep black coral bed by an alien species, Carijoa riisei, off Maui, Hawai'i. Coral Reefs. 2003;22:121-2. https://doi.org/10.1 007/s00338-003-0306-5.

Groner ML, Maynard J, Breyta R, Carnegie RB, Dobson A, Friedman CS, et al. Managing marine disease emergencies in an era of rapid change. Philos Transact Royal Soc B Biol Sci. 2016;371(1689):20150364.

Grosholz E. Ecological and evolutionary consequences of coastal invasions. Trends Ecol Evol. 2002;17(1):22-7.

Gunter G. Marine fishes of Panama as related to the Canal. Gulf Caribbean Res. 1979:6(3):267-73.

Hackerott S, Valdivia A, Cox CE, Silbiger NJ, Bruno JF. Invasive lionfish had no measurable effect on prey fish community structure across the Belizean Barrier Reef. PeerJ. 2017;5:e3270.

Hansen L. Increasing the resistance and resilience of tropical marine ecosystems to climate change. In: Buying time: a user's manual for building resistance and resilience to climate change in natural systems. Washington: WWF; 2003. p. 157-76. https://www.iucn.org/dbtw-wpd/edocs/Atm-Cl-076.pdf.

Harris HE, Fogg AQ, Allen MS, Ahrens RN, Patterson WF. precipitous Declines in northern Gulf of Mexico Invasive Lionfish populations following the emergence of an Ulcerative Skin Disease. Sci Rep. 2020;10:1-7.

Harris HE, Fogg AQ, Yanong RP, Frasca S Jr, Cody T, Waltzek TB, et al. First report of an emerging ulcerative skin disease in invasive lionfish. University of Florida-IFAS Extention. Electron Data Inf Source. 2018:1-7.

Harvell D. Ocean outbreak: confronting the rising tide of marine disease: University of California Press; 2019.

Hawai'i Invasive Species Council (HISC) 2019. Kappaphycus algae, at website: https://dlnr.hawaii.gov/hisc/info/invasive-species-profiles/kappaphycus-algae/.

Henderson EB. Economic and ecological implications of interactions between lobsters and invasive lionfish in the Bahamas. MSc thesis. Canada: Biological Sciences Department, University of British Columbia; 2012.

Hernández L. Potential distribution of the tiger shrimp Penaeus monodon (Decapoda: Penaeidae), an invasive species in the Atlantic Ocean. Rev Biol Trop. 2020;68(1).

Hewitt CL. Distribution and biodiversity of Australian tropical marine bioinvasions. Pac Sci. 2002;56(2):213-22.

Hewitt CL, Campbell ML, Schaffelke B. Introductions of seaweeds: accidental transfer pathways and mechanisms. Bot Mar. 2007;50(5/6):326-37.

Hildebrand SF. The tarpon in the Panama Canal. Sci Mon. 1937;44(3):239-48.

Hixon MA. Predation: piscivory and the ecology of coral-reef fishes. Ecology of fishes on coral reefs. In: Mora C, editor. Ecology of fishes on coral reefs. Cambridge: Cambridge University Press; 2015. p. 41-52. https://doi.org/10.1 017/CBO9781316105412.007.

Hutchings PA, Hilliard RW, Coles SL. Species introductions and potential for marine pest invasions into tropical marine communities, with special reference to the Indo-Pacific. Pac Sci. 2002;56(2):223-33.

Ingeman KE. Lionfish cause increased mortality rates and drive local extirpation of native prey. Mar Ecol Prog Ser. 2016;558:235-45.

Jaafar Z, Yeo DC, Tan HH, O'Riordan RM. Status of estuarine and marine nonindigenous species in Singapore. Raffles Bull Zool Suppl. 2012;25:79-92.

Jeschke JM, Strayer DL. Invasion success of vertebrates in Europe and North America. Proc Natl Acad Sci. 2005;102(20):7198-202.

Kahng SE. Ecological impacts of Carijoa riisei on black coral habitat: Black Coral Science Management Workshop; 2007. p. 18-9.

Kahng SE, Grigg RW. Impact of an alien octocoral, Carijoa riisei, on black corals in Hawai'i. Coral Reefs. 2005;24:556-62. https://doi.org/10.1007/ s00338-005-0026-0.

Kamalakannan B, Jeevamani JJ, Nagendran NA, Pandiaraja D, Chandrasekaran S. Impact of removal of invasive species Kappaphycus alvarezii from coral reef ecosystem in Gulf of Mannar, India. Curr Sci. 2014:1401-8.

Kaufman L, Dayton P. Impacts of marine resource extraction on ecosystem services and sustainability. Nature's Services: Societal Dependence on Natural Ecosystems 1997. In: Hansen L, editor. Increasing the resistance and resilience of tropical marine ecosystems to climate change. Buying time: a user's manual for building resistance and resilience to climate change in natural systems: WWF, Washington; 2003. p. 157-76. http://www.lucn.org/dbtw-wpd/ edocs/Atm-Cl-076.pdf.
Kennedy TA, Naeem S, Howe KM, Knops JM, Tilman D, Reich P. Biodiversity as a barrier to ecological invasion. Nature. 2002;417(6889):636-8.

Kimball ME, Miller JM, Whitfield PE, Hare JA. Thermal tolerance and potential distribution of invasive lionfish (Pterois volitans/miles complex) on the east coast of the United States. Mar Ecol Prog Ser. 2004;283:269-78.

Kindinger TL. Behavioral response of native Atlantic territorial three spot damselfish (Stegastes planifrons) toward invasive Pacific red lionfish (Pterois volitans). Environ Biol Fish. 2015;98(2):487-98.

Kindinger TL, Albins MA. Consumptive and non-consumptive effects of an invasive marine predator on native coral-reef herbivores. Biol Invasions. 2017;19(1):131-46.

Klautau M, Cóndor-Luján B, Azevedo F, Leocorny P, Brandão FD, Cavalcanti FF. Heteropiaglomerosa (Bowerbank, 1873)(Porifera, Calcarea, Calcaronea), a new alien species in the Atlantic. Syst Biodivers. 2020:1-5.

Kletou D, Hall-Spencer JM, Kleitou P. A lionfish (Pterois miles) invasion has begun in the Mediterranean Sea. Marine Biodiversity Records. 2016;9(46):608-26.

Knapp IS, Godwin LS, Smith JE, Williams CJ, Bell JJ. Records of non-indigenous marine species at Palmyra Atoll in the US Line Islands. Marine Biodiversity Records. 2011;4.

Kühn I, Klotz S. From ecosystem invasibility to local, regional and global patterns of invasive species. In: Nentwig W, editor. Biological Invasions. Ecological Studies (Analysis and Synthesis), vol 193. Berlin: Springer; 2008. https://doi. org/10.1007/978-3-540-36920-2_11.

Lages BG, Fleury BG, Ferreira CE, Pereira RC. Chemical defense of an exotic coral as invasion strategy. J Exp Mar Biol Ecol. 2006;328(1):127-35.

Lages BG, Fleury BG, Hovell AM, Rezende CM, Pinto AC, Creed JC. Proximity to competitors changes secondary metabolites of non-indigenous cup corals, Tubastraea spp., in the southwest Atlantic. Mar Biol. 2012;159(7):1551-9.

Lages BG, Fleury BG, Menegola C, Creed JC. Change in tropical rocky shore communities due to an alien coral invasion. Mar Ecol Prog Ser. 2011;438:85-96.

Lages BG, Fleury BG, Pinto AC, Creed JC. Chemical defenses against generalist fish predators and fouling organisms in two invasive ahermatypic corals in the genus Tubastraea. Mar Ecol. 2010a;31(3):473-82.

Lages BG, Fleury BG, Rezende CM, Pinto AC, Creed JC. Chemical composition and release in situ due to injury of the invasive coral Tubastraea (Cnidaria, Scleractinia). Braz J Oceanogr. 2010b;58(SPE4):47-56.

LaJeunesse TC, Lee S, Bush S, Bruno JF. Persistence of non-Caribbean algal symbionts in Indo-Pacific mushroom corals released to Jamaica 35 years ago. Coral Reefs. 2005:24(1):157-9.

Lambert CC, Lambert G. Non-indigenous ascidians in southern California harbors and marinas. Mar Biol. 1998;130(4):675-88.

Lambert G. A global overview of ascidian introductions and their possible impact on the endemic fauna. In: Sawada H, Yokosawa H, Lambert CC, editors. The Biology of Ascidians. Tokyo: Springer; 2001. https://doi.org/10.1007/ 978-4-431-66982-1_40.

Lambert G. Nonindigenous ascidians in tropical waters. Pac Sci. 2002;56(3):291-8.

Lasso-Alcalá O, Nunes JL, Lasso C, Posada J, Robertson R, Piorski NM, et al. Invasion of the indo-pacific blenny Omobranchus punctatus (Perciformes: Blenniidae) on the Atlantic coast of central and south America. Neotrop Ichthyol. 2011;9(3):571-8.

Lesser MP, Slattery M. Phase shift to algal dominated communities at mesophotic depths associated with lionfish (Pterois volitans) invasion on a Bahamian coral reef. Biol Invasions. 2011;13(8):1855-68.

Lessios HA. Mass mortality of Diadema antillarum in the Caribbean: what have we learned? Annu Rev Ecol Syst. 1988;19(1):371-93.

Lessios HA, Robertson DR, Cubit JD. Spread of Diadema mass mortality through the Caribbean. Science. 1984;226(4672):335-7.

Lo CM, Morand S, Galzin R. Gill parasites of Cephalopholis argus (Teleostei: Serranidae) from Moorea (French Polynesia): site selection and coexistence. Folia Parasitol. 2001;48(1):30-6.

Lohan KM, Ruiz GM, Torchin ME. Invasions can drive marine disease dynamics. Marine Dis Ecol. 2020;115.

López C, Clemente S, Moreno S, Ocaña O, Herrera R, Moro L, et al. Invasive Tubastraea spp. and Oculina patagonica and other introduced scleractinians corals in the Santa Cruz de Tenerife (Canary Islands) harbor: Ecology and Potential Risks. Reg Stud Mar Sci. 2019;29:100713.

Lugo AE. Mangrove forests: a tough system to invade. In: Britton KO, editor Exotic pests of eastern forests conference proceedings; 1997. Nashville: US Forest Service and Tennessee Exotic Pest Plant Council; 1998. p. 195-8.

Lutz-Collins V, Ramsay A, Quijón PA, Davidson J. Invasive tunicates fouling mussel lines: evidence of their impact on native tunicates and other epifaunal invertebrates. Aquat Invasions. 2009;4(1):213-20. 
Luz BL, Capel KC, Zilberberg C, Flores AA, Migotto AE, Kitahara MV. A polyp from nothing: The extreme regeneration capacity of the Atlantic invasive sun corals Tubastraea coccinea and T. tagusensis (Anthozoa, Scleractinia). J Exp Mar Biol Ecol. 2018:503:60-5.

Lymbery AJ, Morine M, Kanani HG, Beatty SJ, Morgan DL. Co-invaders: the effects of alien parasites on native hosts. Int J Parasitol Parasites Wildlife. 2014;3(2): $171-7$

Mack RN, Simberloff D, Mark Lonsdale W, Evans H, Clout M, Bazzaz FA. Biotic invasions: causes, epidemiology, global consequences, and control. Ecol Appl. 2000;10(3):689-710.

Mantelatto MC, Creed JC. Non-indigenous sun corals invade mussel beds in Brazil. Mar Biodivers. 2015;45(4):605-6.

Mantelatto MC, Creed JC, Mourão GG, Migotto AE, Lindner A. Range expansion of the invasive corals Tubastraea coccinea and Tubastraea tagusensis in the Southwest Atlantic. Coral Reefs. 2011;30(2):397.

Mantelatto MC, da Silva AG, dos Santos LT, McFadden CS, Creed JC. Invasion of aquarium origin soft corals on a tropical rocky reef in the southwest Atlantic, Brazil. Marine Pollut Bull. 2018;130:84-94.

Marchini A, Ferrario J, Minchin D. Marinas may act as hubs for the spread of the pseudo-indigenous bryozoan Amathia verticillata (Delle Chiaje, 1822) and its associates. Sci Mar. 2015;79(3):355-65.

Marins FO, Novaes RL, Rocha RM, Junqueira AO. Non indigenous ascidians in port and natural environments in a tropical Brazilian bay. Zoologia (Curitiba). 2010;27(2):213-21.

Martinez JA, Smith CM, Richmond RH. Invasive algal mats degrade coral reef physical habitat quality. Estuar Coast Shelf Sci. 2012;99:42-9.

Martinez JA, Wolanski E, Richmond RH. The effects of an alien invasive alga on sediment retention and resuspension in coastal Hawaiian waters and the influence of community based restoration. In: The Fifth Education and Science Forum. Washington; 2009. (Abstract)

McCann L, Keith I, Carlton J, Ruiz G, Dawson T, Collins K. First record of the nonnative bryozoan Amathia (= Zoobotryon) verticillata (delle Chiaje, 1822) (Ctenostomata) in the Galápagos Islands. Biolnvasions Records. 2015;4(4):255-60.

McCann LD, Hitchcock NG, Winston JE, Ruiz GM. Non-native bryozoans in coastal embayments of the southern United States: new records for the western Atlantic. Bull Mar Sci. 2007;80(2):319-42.

McCosker JE, Dawson CE. Biotic passage through the Panama Canal, with particular reference to fishes. Mar Biol. 1975;30(4):343-51.

McCuller MI, Carlton JT. Transoceanic rafting of Bryozoa (Cyclostomata, Cheilostomata, and (tenostomata) across the North Pacific Ocean on Japanese tsunami marine debris. Aquat Invasions. 2018;13(1).

Minchin D, Liu TK, Cheng M. First Record of Bryozoan Amathia (= Zoobotryon) verticillata (Bryozoa: Vesiculariidae) from Taiwan. Pac Sci. 2016;70(4):509-17.

Miranda AA, Almeida AC, Vieira LM. Non-native marine bryozoans (Bryozoa: Gymnolaemata) in Brazilian waters: Assessment, dispersal and impacts. Mar Pollut Bull. 2018c;130:184-91.

Miranda RJ, Costa Y, Lorders FL, José de Anchieta CC, Barros F. New records of the alien cup-corals (Tubastraea spp.) within estuarine and reef systems in Todos os Santos Bay, Southwestern Atlantic. Marine Biodiversity Records. 2016a;9(1):35.

Miranda RJ, Cruz IC, Barros F. Effects of the alien coral Tubastraea tagusensis on native coral assemblages in a southwestern Atlantic coral reef. Mar Biol. 2016b;163(3):45.

Miranda RJ, José de Anchieta CC, Mariano-Neto E, Sippo JZ, Barros F. Do invasive corals alter coral reef processes? An empirical approach evaluating reef fish trophic interactions. Mar Environ Res. 2018a;138:19-27.

Miranda RJ, Tagliafico A, Kelaher BP, Mariano-Neto E, Barros F. Impact of invasive corals Tubastrea spp. on native coral recruitment. Mar Ecol Prog Ser. 2018b; 605:125-33.

Mitchell MD, Harborne AR. Non-consumptive effects in fish predator-prey interactions on coral reefs. Coral Reefs. 2020:1-8.

Mizrahi D, Navarrete SA, Flores AA. Groups travel further: pelagic metamorphosis and polyp clustering allow higher dispersal potential in sun coral propagules. Coral Reefs. 2014;33(2):443-8.

Moberg F, Folke C. Ecological goods and services of coral reef ecosystems. Ecol Econ. 1999;29(2):215-33.

MoEF\&CC Project Report. Project Report submitted to Ministry of Environment, Forest and Climate Change by Suganthi Devadason Marine Research Institute. 2018.

Molnar JL, Gamboa RL, Revenga C, Spalding MD. Assessing the global threat of invasive species to marine biodiversity. Front Ecol Environ. 2008;6(9): 485-92.
Mumby PJ. Phase shifts and the stability of macroalgal communities on Caribbean coral reefs. Coral Reefs. 2009;28(3):761-73.

Mundy BC. Checklist of the fishes of the Hawai'i an Archipelago. Bishop Museum Bull Zool. 2005;6:1-704.

Neilson BJ, Wall CB, Mancini FT, Gewecke CA. Herbivore biocontrol and manual removal successfully reduce invasive macroalgae on coral reefs. PeerJ. 2018;6: e5332.

Occhipinti-Ambrogi A. Global change and marine communities: alien species and climate change. Mar Pollut Bull. 2007;55(7-9):342-52.

O'Connor M, Hawkins C, Loomis DK. A manual of previously recorded non-indigenous invasive and native transplanted animal species of the Laurentian Great Lakes and coastal United States. Technical Memorandum NOS NCCOS 77. 2008. 82.

Oda DK, Parrish JD. Ecology of commercial snappers and groupers introduced to Hawai'i an reefs. In: $4^{\text {th }}$ International Coral Reef Symposium. Manila (Philippines); 1981. p. 18-22.

Olinger LK, Heidmann SL, Durdall AN, Howe C, Ramseyer T, Thomas SG, et al. Altered juvenile fish communities associated with invasive Halophila stipulacea seagrass habitats in the US Virgin Islands. PLoS One. 2017;12(11).

Padilla DK, Williams SL. Beyond ballast water: aquarium and ornamental trades as sources of invasive species in aquatic ecosystems. Front Ecol Environ. 2004; 2(3):131-8.

Padmakumar K, Chandran R, Kumar YSY, Sornaraj R. Carijoa riisei (Cnidaria : Octocorallia: Clavulariidae), a newlyobserved threat to Gulf of Mannar coral biodiversity? Curr Sci. 2011;100:35-7.

Patterson Edward JK, Bhatt JR. Impacts of cultivation of Kappaphycus alvarezii on coral reef environs of the Gulf of Mannar and Palk Bay, South-eastern India. Invasive alien plants: an ecological appraisal for the Indian subcontinent 2012;89-98.

Peyton KA. Aquatic invasive species impacts in Hawaiian soft sediment habitats. PhD thesis, University of Hawaii at Manoa; 2009.

Pinault M, Wickel J, Nicet JB, Chenoz M, de Montgolfier B, Fricke R. First record of the near threatened native seahorse Hippocampus reidi (Teleostei: Syngnathidae) in an ecosystem dominated by the invasive seagrass Halophila stipulacea in the Caribbean Sea. Cybium. 2018;42(4):393-6.

Precht WF, Gintert BE, Robbart ML, Fura R, Van Woesik R. Unprecedented diseaserelated coral mortality in Southeastern Florida. Sci Rep. 2016;6:1.

Prenter J, MacNeil C, Dick JT, Dunn AM. Roles of parasites in animal invasions. Trends Ecol Evol. 2004;19(7):385-90.

Quintanilla E, Wilke T, Ramírez-Portilla C, Sarmiento A, Sánchez JA. Taking a detour: invasion of an octocoral into the Tropical Eastern Pacific. Biol Invasions. 2017;19(9):2583-97.

Raghunathan C, Venkataraman K, Satyanarayana C, Rajkumar R. An invasion of snowflake coral Carijoa riisei (Duchassaing and Michelotti 1860) in Indian seas: threats to coral reef ecosystem. In: Venkataraman K, Sivaperuman C, Raghunathan C, editors. Ecology and Conservation of Tropical Marine Faunal Communities. Berlin: Springer; 2013. https://doi.org/10.1007/978-3642-38200-0_24.

Randall JE. Introductions of marine fishes to the Hawai'i an Islands. Bull Mar Sci. 1987:41(2):490-502.

Raymond WW, Albins MA, Pusack TJ. Competitive interactions for shelter between invasive Pacific red lionfish and native Nassau grouper. Environ Biol Fish. 2015;98(1):57-65.

Robertson DR, Kingon K, Baksh S, Estapé CJ, Morgan EA. The Indo-Pacific damselfish Neopomacentrus cyanomos at Trinidad, southeast Caribbean. Aquat Invasions. 2021:16.

Robertson DR, Simoes N, Gutierrez Rodriguez C, Piñeros VJ, Perez-España H. An Indo-Pacific damselfish well established in the southern Gulf of Mexico: prospects for a wider, adverse invasion. J Ocean Sci Foundation. 2016;19:1-17.

Rodgers S, Cox EF. Rate of Spread of Introduced Rhodophytes Kappaphycus alvarezii, Kappaphycus striatum, and Gracilaria salicornia and Their Current Distribution in Kāne'ohe Bay, O'ahu Hawai'i. Pac Sci. 1999;53(3):232-41.

Rogers CS, Willette DA, Miller J. Rapidly spreading seagrass invades the Caribbean with unknown ecological consequences. Front Ecol Environ. 2014;12(10):546-7.

Rossi G, Montori S, Cerrano C, Calcinai B. The coral killing sponge Chalinula nematifera (Porifera: Haplosclerida) along the eastern coast of Sulawesi Island (Indonesia). Ital J Zool. 2015;82(1):143-8.

Ruiz GM, Carlton JT, Grosholz ED, Hines AH. Global invasions of marine and estuarine habitats by non-indigenous species: mechanisms, extent, and consequences. Am Zool. 1997;37(6):621-32. 
Ruiz H, Ballantine DL. Occurrence of the seagrass Halophila stipulacea in the tropical west Atlantic. Bull Mar Sci. 2004;75(1):131-5.

Ruiz H, Ballantine DL, Sabater J. Continued spread of the seagrass Halophila stipulacea in the Caribbean: documentation in Puerto Rico and the British Virgin Islands. Gulf Caribbean Res. 2017;28(1):5-7.

Russell DJ. The ecological invasion of Hawai'i an reefs by two marine red algae, Acanthophora spicifera (Vahl) Boerg. and Hypnea musciformis (Wulfen) J. Ag. and their association with two native species, Laurencia nidifica. ICES Marine Science Symposium. 1992;194:110-25.

Russell DJ, Balazs GH. Colonization by the alien marine alga Hypned musciformis (Wulfen) J. Ag. (Rhodophyta: Gigartinales) in the Hawai'i an Islands and its utilization by the green turtle, Chelonia mydas L. Aquat Bot. 1994:47(1):53-60.

Russell DJ, Balazs GH. Increased use of non-native algae species in the diet of the green turtle (Chelonia mydas) in a primary pasture ecosystem in Hawaii. Aquat Ecosyst Health Manag. 2015;18(3):342-6.

Sammarco PW, Porter SA, Cairns SD. A new coral species introduced into the Atlantic Ocean Tubastraea micranthus (Ehrenberg 1834)(Cnidaria, Anthozoa, Scleractinia): an invasive threat? Aquat Invasions. 2010:5(2):131-40.

Sammarco PW, Porter SA, Sinclair J, Genazzio M. Depth distribution of a new invasive coral (Gulf of Mexico)-Tubastraea micranthus, comparisons with $T$. coccinea, and implications for control. Manage Biol Invasions. 2013;4:291.

Sammarco PW, Porter SA, Sinclair J, Genazzio M. Population expansion of a new invasive coral species, Tubastraea micranthus, in the northern Gulf of Mexico. Mar Ecol Prog Ser. 2014;495:161-73.

Sampaio CL, Miranda RJ, Maia-Nogueira R. José de Anchieta CC. New occurrences of the nonindigenous orange cup corals Tubastraea coccinea and T. tagusensis (Scleractinia: Dendrophylliidae) in Southwestern Atlantic. Check List. 2012;8(3):528-30.

Sánchez JA, Ballesteros D. The invasive snowflake coral (Carijoa riisei) in the Tropical Eastern Pacific, Colombia. Rev Biol Trop. 2014;62:199-207.

Schofield PJ. Geographic extent and chronology of the invasion of non-native lionfish (Pterois volitans [Linnaeus 1758] and P. miles [Bennett 1828]) in the Western North Atlantic and Caribbean Sea. Aquat Invasions. 2009;4(3):473-9.

Schofield PJ. Update on geographic spread of invasive lionfishes (Pterois volitan [Linnaeus, 1758] and P. miles [Bennett, 1828]) in the Western North Atlantic Ocean, Caribbean Sea and Gulf of Mexico. Aquat Invasions. 2010; 5(Supplement 1):S117-22.

Schofield PJ, Akins L. Non-native marine fishes in Florida: Updated checklist, population status and early detection/rapid response. Biolnvasions Records. 2019;8(4):898-910.

Schumacher BD, Parrish JD. Spatial relationships between an introduced snapper and native goatfishes on Hawai'i an reefs. Biol Invasions. 2005;7(6):925-33.

Sellers AJ, Ruiz GM, Leung B, Torchin ME. Regional variation in parasite species richness and abundance in the introduced range of the invasive lionfish, Pterois volitans. PLoS One. 2015b;10(6):e0131075.

Sellers AJ, Saltonstall K, Davidson TM. The introduced alga Kappaphycus alvarezil (Doty ex PC Silva, 1996) in abandoned cultivation sites in Bocas del Toro, Panama. Biolnvasions Records. 2015a;4:1-7.

Semmens BX, Buhle ER, Salomon AK, Pattengill-Semmens CV. A hotspot of nonnative marine fishes: evidence for the aquarium trade as an invasion pathway. Mar Ecol Prog Ser. 2004;266:239-44.

Sheets EA, Cohen CS, Ruiz GM, Da Rocha RM. Investigating the widespread introduction of a tropical marine fouling species. Ecol Evol. 2016;6(8): 2453-71.

Shenkar N, Swalla BJ. Global diversity of Ascidiacea. PLoS One. 2011;6(6).

Shih JL. The Influence of a Pacific Invasive Sponge on Coral Reef Dynamics in Hawai 'i. Doctoral dissertation, University of Hawai'i at Mānoa. 2018.

Short F, Carruthers T, Dennison W, Waycott M. Global seagrass distribution and diversity: a bioregional model. J Exp Mar Biol Ecol. 2007;350(1-2):3-20.

Short FT, Polidoro B, Livingstone SR, Carpenter KE, Bandeira S, Bujang JS, et al. Extinction risk assessment of the world's seagrass species. Biol Conserv. 2011; 144(7):1961-71.

Silva R, Vinagre C, Kitahara MV, Acorsi IV, Mizrahi D, Flores AA. Sun coral invasion of shallow rocky reefs: effects on mobile invertebrate assemblages in Southeastern Brazil. Biol Invasions. 2019;A21(4):1339-50.

Simberloff D. Non-native species do threaten the natural environment! J Agric Environ Ethics. 2005;18(6):595-607.

Smith JE, Hunter CL, Conklin EJ, Most R, Sauvage T, Squair C, et al. Ecology of the invasive red alga Gracilaria salicornia (Rhodophyta) on O'ahu, Hawai'i. Pac Sci. 2004;58(2):325-43.
Smith JE, Hunter CL, Smith CM. Distribution and reproductive characteristics of nonindigenous and invasive marine algae in the Hawai'i an Islands. Pac Sci. 2002;56(3):299-315.

Smulders FO, Vonk JA, Engel MS, Christianen MJ. Expansion and fragment settlement of the non-native seagrass Halophila stipulacea in a Caribbean bay. Mar Biol Res. 2017;13(9):967-74.

Soares BE, Raiol RD, Montag LD. Occurrence of the non-native blenny Omobranchus punctatus (Valenciennes, 1836) (Perciformes: Blenniidae) in the Amazon coastal zone, Brazil. Aquat Invasions. 2011;6(Supplement 1):S39-43.

Spalding MD, Fox HE, Allen GR, Davidson N, Ferdaña ZA, Finlayson MA, et al. Marine ecoregions of the world: a bioregionalization of coastal and shelf areas. BioScience. 2007:57(7):573-83.

Steiner SC, Willette DA. The expansion of Halophila stipulacea (Hydrocharitaceae, Angiospermae) is changing the seagrass landscape in the commonwealth of Dominica, Lesser Antilles. Caribbean Naturalist. 2015;22:1-9.

Stelfox M, Lett C, Reid G, Souch G, Sweet M. Minimum drift times infer trajectories of ghost nets found in the Maldives. Mar Pollut Bull. 2020;154: 111037.

Sulu R, Kumar L, Hay C, Pickering T. Kappaphycus seaweed in the Pacific: review of introductions and field testing proposed quarantine protocols. Noumea: Secretariat of the Pacific Community; 2004. p. 1-84.

Swanson P. Tarpon in the Pacific. Copeia. 1946;3:175.

Sweet M, Burian A, Bulling M. Corals as canaries in the coalmine: towards the incorporationof marine ecosystems into the 'One Health'concept. J Invertebr Pathol. 2021:107538.

Sweet MJ, Bateman KS. Reprint of 'Diseases in marine invertebrates associated with mariculture and commercial fisheries'. J Sea Res. 2016;113:28-44.

Sweetman AK, Middelburg JJ, Berle AM, Bernardino AF, Schander C, Demopoulos AW, et al. Impacts of exotic mangrove forests and mangrove deforestation on carbon remineralization and ecosystem functioning in marine sediments. Biogeosciences. 2010;7(7).

Tamilselvi M, Sivakumar V, Abdul Jaffar Ali H, Thilaga RD. Distribution of alien tunicates (Ascidians) in Tuticorin coast, India. World J Zool. 2011;6(2):164-72.

Teixeira LM, Creed JC. A decade on: an updated assessment of the status of marine non-indigenous species in Brazil. Aquat Invasions. 2020;15(1):30-43.

Torchin M, Lafferty KD, Kuris AM. Parasites and marine invasions. Parasitology. 2002;124(7):137.

Turicchia E, Hoeksema BW, Ponti M. The coral-killing sponge Chalinula nematifera as a common substrate generalist in Komodo National Park, Indonesia. Mar Biol Res. 2018;14(8):827-33.

U.S. Coast Guard. Ballast Water Best Management Practices to Reduce the Likelihood of Transporting Pathogen That May Spread Stony Coral Tissue Loss Disease. Marine Saf Inform Bull. 2019:07-19 https://www.dco.uscg.mil/ Portals/9/DCO\%20Documents/5p/MSIB/2019/MSIB_007_19.pdf?ver=2019-0906-151207-643.

van Ofwegen LP. A new genus of nephtheid soft corals (Octocorallia: Alcyonacea: Nephtheidae) from the Indo-Pacific. Natl Natuurhistorisch Museum. 2005.

Van Ofwegen LP, Haddad MA. A probably invasive new genus and new species of soft coral (Octocorallia: Alcyonacea: Clavulariidae) from Brazil. Zootaxa. 2011;3107(1):38-46.

Van Soest RW, Boury-Esnault N, Vacelet J, Dohrmann M, Erpenbeck D, De Voogd NJ, et al. Global diversity of sponges (Porifera). PLoS One. 2012;7(4):e35105.

Van Tussenbroek BI, Van Katwijk MM, Bouma TJ, Van der Heide T, Govers LL, Leuven RS. Non-native seagrass Halophila stipulacea forms dense mats under eutrophic conditions in the Caribbean. J Sea Res. 2016;115:1-5.

Vaughan TW, Wells JW. Revision of the suborders, families and genera of Scleractinia. Geol Soc Am Spec Pap. 1943;44:1-363.

Vega A, Vergara Y, Robles-P Y. First record of the cobia Rachycentron canadum Linnaeus (Pisces: Rachycentridae) in the Panamanian Pacific. Tecnociencia. 2016:18:13-9

Vera B, Collado-Vides L, Moreno C, van Tussenbroek BI. Halophila stipulacea (Hydrocharitaceae): a recent introduction to the continental waters of Venezuela. Caribb J Sci. 2014;48(1):66-70.

Vicente J, Silbiger NJ, Beckley BA, Raczkowski CW, Hill RT. Impact of high pCO2 and warmer temperatures on the process of silica biomineralization in the sponge Mycale grandis. ICES J Mar Sci. 2016;73(3):704-14.

Vignon M, Sasal P. Fish introduction and parasites in marine ecosystems: a need for information. Environ Biol Fish. 2010;87(1):1-8.

Vignon M, Sasal P, Galzin R. Host introduction and parasites: a case study on the parasite community of the peacock grouper Cephalopholis argus (Serranidae) in the Hawaiian Islands. Parasitol Res. 2009;104(4):775. 
Wade RM, Spalding HL, Peyton KA, Foster K, Sauvage T, Ross M, et al. A new record of Avrainvillea cf. erecta (Berkeley) A. Gepp \& ES Gepp (Bryopsidales, Chlorophyta) from urbanized estuaries in the Hawaiian Islands. Biodiversity Data J. 2018;6.

Walker PJ, Mohan CV. Viral disease emergence in shrimp aquaculture: origins, impact and the effectiveness of health management strategies. Rev Aquac 2009;1(2):125-54

Wallentinus I, Nyberg CD. Introduced marine organisms as habitat modifiers. Mar Pollut Bull. 2007;55(7-9):323-32.

Walther GR, Roques A, Hulme PE, Sykes MT, Pyšek P, Kühn I, et al. Alien species in a warmer world: risks and opportunities. Trends Ecol Evol. 2009;24(12):686-93.

Wells FE, Bieler R. A low number of introduced marine species at low latitudes: a case study from southern Florida with a special focus on Mollusca. Manage Biol Invasions. 2020;11(3):372.

Wells JW. Notes on indo-Pacific scleractinian corals. Part 9. New corals from the Galapagos Islands. 1982.

Whitfield PE, Gardner T, Vives SP, Gilligan MR, Courtenay WR Jr, Ray GC, et al. Biological invasion of the Indo-Pacific lionfish Pterois volitans along the Atlantic coast of North America. Mar Ecol Prog Ser. 2002;235:289-97.

Willette DA, Ambrose RF. The distribution and expansion of the invasive seagrass Halophila stipulacea in Dominica, West Indies, with a preliminary report from St. Lucia. Aquat Bot. 2009;91(3):137-42.

Willette DA, Ambrose RF. Effects of the invasive seagrass Halophila stipulacea on the native seagrass, Syringodium filiforme, and associated fish and epibiota communities in the Eastern Caribbean. Aquat Bot. 2012;103:74-82.

Willette DA, Chalifour J, Debrot AD, Engel MS, Miller J, Oxenford HA, et al. Continued expansion of the trans-Atlantic invasive marine angiosperm Halophila stipulacea in the Eastern Caribbean. Aquat Bot. 2014;112:98-102.

Willette DA, Chiquillo KL, Cross C, Fong P, Kelley T, Toline CA, et al. Growth and recovery after small-scale disturbance of a rapidly-expanding invasive seagrass in St. John, US Virgin Islands. J Exp Mar Biol Ecol. 2020;523:151265.

Williams SL. Introduced species in seagrass ecosystems: Status and concerns. J Ex Mar Biol Ecol. 2007;350(1-2):89-110.

Williams SL, Smith JE. A global review of the distribution, taxonomy, and impacts of introduced seaweeds. Annu Rev Ecol Evol Syst. 2007;38:327-59.

Worm B, Lotze HK. Marine biodiversity and climate change. Climate Change. 2016:195-212.

Young HS, Parker IM, Gilbert GS, Guerra AS, Nunn CL. Introduced species, disease ecology, and biodiversity-disease relationships. Trends Ecol Evol. 2017;32(1): $41-54$.

Zhang Y, Deegan L, Carman MR. Invasive tunicate (Ascidiacea) metabolic and filtration rates in comparison to native tunicate and bivalve species. Manage Biol Invasions. 2019;10(4):617-25.

\section{Publisher's Note}

Springer Nature remains neutral with regard to jurisdictional claims in published maps and institutional affiliations.

Ready to submit your research? Choose BMC and benefit from:

- fast, convenient online submission

- thorough peer review by experienced researchers in your field

- rapid publication on acceptance

- support for research data, including large and complex data types

- gold Open Access which fosters wider collaboration and increased citations

- maximum visibility for your research: over $100 \mathrm{M}$ website views per year

At BMC, research is always in progress.

Learn more biomedcentral.com/submissions 